\title{
HARTOS DE MIRAR SIN VER. ÉTICAS DE LA MIRADA, POLÍTICAS DEL LENGUAJE Y POESÍA ESPAÑOLA CONTEMPORÁNEA, A PARTIR DE UN CASO DE ESTUDIO: DOMINIOS DE MATIZ (2010) DE JUAN PASTOR ${ }^{1}$.
}

GERMÁN LABRADOR

Princeton University

\begin{abstract}
Resumen
Este trabajo problematiza la condiciones que definen la poesía española contemporánea, en tanto que tecnología de representación constituida social e históricamente, a partir de una crítica de las teorías poéticas vigentes que sea a la vez un análisis de su teoría de la visión. El artículo examina cómo, de modo procesual, la poesía española actual se relaciona problemáticamente con la sociedad civil y con los distintos pasados literarios que la constituyen hoy como institución. Me serviré Dominios de matiz de Juan Pastor como caso de estudio que textualiza esa problemática en la medida en que trata de hacerse cargo de la misma.
\end{abstract}

Palabras clave: poesía social, poéticas contemporánea, Juan Pastor, rap español, tradiciones poéticas, antifranquismo, mayo de 1968 en España, imaginación política, teorías de la visión, identidad del poeta.

\begin{abstract}
This article problematizes conditions of today's Spanish poetry, viewed as a socially and historically motivated technology of representation, and analyzed after its own poetical theories of the vision. This article want to examine how, by this process, current Spanish poetry fell into a problematic relationship to civil society and to the different literary pasts that have constituted Spanish poetry as institution nowadays. In this attempt, it uses Dominios de matiz by Juan Pastor as study case, since it formalizes this very same problematic by trying to give it an impossible answer.
\end{abstract}

Keywords: social poetry, contemporary poetics, Juan Pastor, Spanish rap, poetical traditions, anti-Francoism, Spanish 1968 May, political imagination, theories of the vision, identity of the poet.

Frente a frente. Contra un espejo. Así se inicia el prólogo de este poemario: "Figura frente al espejo", donde el poeta convoca una imagen (de si mismo) que no acude, en la que no se reconoce, o en la que simplemente no se puede ver ${ }^{2}$. A este acto

\footnotetext{
${ }^{1}$ Universidad de Princeton (USA). Correo: labrador@princeton.edu. Recibido: 15-01-2011. Aceptado: 30-03-2011.

${ }^{2}$ Este texto en su fase inicial comenzó siendo una reseña de Dominios de matiz, pero la complejidad de los argumentos que se derivaban de aquella reseña hizo conveniente darle un desarrollo superior, estimulado por la generosa lectura de varios colegas. En su forma actual, la lectura crítica del poemario ha sido reducida a la condición de caso de estudio de un problema mucho más amplio, que implica la
} 
inicial de duplicación y desreconocimiento siguen toda una serie de desdoblamientos: voz de la escritura y voz real; voz del presente y voz del pasado; rostro propio y propia mirada del rostro construyen juegos de tensiones en los dos primeros poemas del libro $^{3}$. Aunque aspiran a su reconocimiento, frente al espejo, las dos figuras que se nos proponen desde el comienzo no pueden identificarse. Toda esta escena tiene lugar en un amanecer. A partir de este momento, quedan definidas como magnitudes clave de todo el poemario la línea, la luz y el matiz, estrategias textuales con que representar la distancia que se construye entre espejo y figura, que organizan una economía de distancias, de entendimientos y de símbolos, en lo que ya podemos llamar el paisaje moral del poemario, su particular carte du tendre ${ }^{4}$.

El segundo de estos poemas-prólogo se propone como "pórtico" y anuncia "la llegada de la estación y su color", lo que es como decir la sucesión de las otras cuatro partes del libro que, a la manera de four quartets, proponen una secuencia de tiempos y ámbitos marcadamente cereal, a la manera de tres estaciones y un epílogo otoñal, una "estación final". En este caso, la referencia más que a Eliot, parece ser al ValleInclán de las Sonatas, libro citado en varios momentos del poemario. Finalmente, acaba siendo el tiempo del estío, el tiempo de un otoño que avanza, el que define la tonalidad (musicalmente menor) de Dominios de matiz, que, entre timbres sombríos

teoría poética y los modos de relación con pasados literarios que se pueden apreciar en la poesía contemporánea española.

${ }^{3}$ Juan Pastor no se inventa esta técnica de comenzar un poema frente al espejo, como excusa narrativa para desplegar la temporalidad del poema como movimiento corporal hacia el pasado, que retorna y se fractura sobre la superficie de ese espejo, convertido en presente. En el espacio de la poesía menor transicional, cabe mencionar un libro fascinante, que carece hoy de una inscripción nítida en el archivo poético del periodo. Se trata del texto de Javier Villán, El rostro en el espejo. Poema 1976-1977, obra de este poeta militante, quien, en 1977, desde Rimbaud, Pasolini y Gramsci, propone una historia de la derrota de las aspiraciones utópicas de la izquierda política que es, en realidad, una memoria de la educación sentimental bajo el franquismo; su técnica narrativa presenta una figura frente al espejo (del pasado) que no se reconoce en él y que abre sobre su superficie (en el poema) la posibilidad de recomponer un nosotros expropiado por la historia. Otro autor que ha explorado este desdoblamiento especular como inicio narrativo, que comporta una ética y una memoria también de la transición española, es Pere Gimferrer en Mascarada, ahora desde Aragon y cierta poesía francesa, como puse de relieve en un trabajo (2003a). También como antecedente, aunque no necesariamente genealógico, en la inventio narratológica de Dominios de matiz, es necesario citar a Jorge Luis Borges, no sólo sobre esta cuestión sino, en particular, en todo lo que se refiere a la fenomenología de un pasaje mental y un trabajo exigente con el vocabulario y la poética de la sombra, como veremos.

${ }^{4}$ La aspiración a resolver el espacio de lo íntimo como referencia de un mundo territorial, sensible por lo tanto a su representación cartográfica (un mapa del alma, una topografía sentimental...), es determinante en toda poética de estirpe simbolista, que convierte la actividad lírica en la descripción de un paisaje del alma, techné que ha servido para caracterizar los desarrollos centrales de la poesía moderna, y componente básico de algunas de las obras que hoy configuran puntos de referencia en el sistema poético español. Juan Pastor, con las matizaciones que plantearé en este trabajo, se inscribe en esta dominante línea de producción poética, dentro del ala más racionalista de la misma, en lo que ha podido ser conceptuado como poética neometafísica. La ductilidad de este término nos habla más bien de una débil demanda a la hora de describir los territorios en los que el simbolismo se expresa, aún hoy en día, como matriz de expresión poética en apariencia no necesitada de legitimación, por más que entre ella y otras lenguas sociales existan cortes de lenguaje insalvables. En todo caso, esa posición racionalista se informa en este poemario mediante el predominio de nociones matemáticas y geométricas a la hora de dar forma y relieve a ese paisaje, en detrimento de otros lenguajes del espacio (otras espacialidades) con contenido geográfico. 
y oros melancólicos, proclama el triunfo de los matices, de las nuances. Si, dentro del poemario, la primavera (que funciona como tiempo del pasado, de la memoria, pero también como tiempo duplicado en que fueron escritos los libros anteriores) se caracteriza por un vigoroso cromatismo (masas totales, intensidad, luces, capas...), en el doble plano de la memoria, en el que el poemario siempre se duplica, todo el trabajo en la escala de color apela directamente al matiz, y la posibilidad de su dominio. El poeta nos hace querer no el color, pero tan solo los matices, diríamos glosando a Rimbaud, en L'Art Poétique (1874), pieza clave del debate estético moderno:
Car nous voulons la Nuance encor,
Pas la Couleur, rien que la nuance !
Oh! la nuance seule fiance
Le rêve au rêve et la flûte au cor ! (104)
Porque queremos el Matiz todavía,
¡No el Color, nada más que el matiz!
¡Oh!, jel matiz por mismo casa
el sueño con el sueño y la flauta con el corno! $!^{5}$

Un reino (king-dom), un dominio, es decir, un espacio sometido a la posibilidad del control y a la autoridad de un dominus, un señor. El poeta, entonces, como señor de los matices, y este libro cuenta sus intentos de conquista de tal feudo (fief-dom), y, tal vez, el relato de su destrucción futura o "profecía" de su pérdida ${ }^{6}$, en el plano doble de su página, y de la referencialidad vital que dice espejar problemáticamente. Todo el trabajo de atmósferas del libro, lo que supone su más notable apuesta retórica (como se puede percibir desde una primera lectura), está dirigido a establecer los contornos de tal dominio. Ello requiere una fuerte inversión de recursos poéticos destinados a determinar el lugar de las líneas, las verticales, o la posición del horizonte, la definición de un contorno y de unos límites. Estas fronteras, bordes, siempre serán difusos, problemáticos, amenazados siempre por otras presencias fuera de dominio, que los comprometen y que los invalidan. El poemario, al tiempo que determina una marca, vuelve extenso todo lo que cae fuera de ella, y tal extensión sin límite, ni cifra, ni cuantificación, es amenaza cerniéndose sobre ese pequeño ámbito de matices reunidos. Fuera de él se intuye lo que nunca se acaba: con tonos de sombra se intuye lo que está fuera del reino, y es inexistencia, oscuridad, tinieblas.

\footnotetext{
${ }^{5}$ La traducción es mía.

${ }^{6}$ El relato filosófico de esta operación conduce a una reflexión sobre la separación y yuxtaposición de esferas públicas y privadas, donde se invierten aquí los términos y se construye el ámbito poético de lo íntimo como ámbito de lo privado, sí pero de lo privado-político, frente a la descripción de lo exterior a este dominio, como ámbito económico, desde la noción de una privatización de la esfera de lo público. Este debate contemporáneo (Bauman, Sloterdijk, Sandel...), intrínsecamente vinculado a la noción de neoliberalismo y globalización, se actualiza intuitivamente en el libro de poemas que nos ocupa, como iremos registrando en este texto. Tal y como se refería supra, aquí, para, ello se recupera una noción clave para la ciencia de la economía política: la idea del dominio, como ámbito doméstico, espacio del domus, y de la oeconomica (Brunner). Como veremos, contra-intuitivamente, lo doméstico en Pastor es el lugar de la política. Más allá de la capacidad de apelar a ese debate político y filosófico que nos es contemporáneo, cabe preguntarse por la ausencias y existencias de un diálogo de fondo con esos debates por parte de los poetas contemporáneos, y de sus críticos.
} 
Frente a la amenaza de la indefinición, del retorno a un mundo de tinieblas (¿primigenias?), en algunos poemas se destaca una delgada línea, intensa, resistente, como en el horizonte una corteza de luz que nunca se extinguiese, algo así como el mediodía de la noche polar o el sol de medianoche, fenómenos ópticos posibles sólo en latitudes extremas: "Y cuando aparezca la sombra que cierra para completar su ocupación, / vendrá el color rojo que sobre una línea horizontal y de futuro, le dará paso a la noche". Esa línea actúa como referente en el poemario, como un paisaje que se despliega hacia adelante, como una especie de afirmación del lugar de su temporalidad por diferir. La línea siempre se escribe en un lugar otro que el matiz, con su sugerencia cromática, con su intensidad o su profundidad. Línea y matiz, con Derrida, están en este poemario relación de suplemento.

Geometrías de un espacio poético. Dentro del dominio se despliegan amplia gama de términos abstractos. Los más, ya lo hemos dicho, van dirigidos a insinuar un reino de lo físico, aunque éste se proponga siempre desmaterializado: "verdes en masa decadente, de tonalidad, de vacío y sombra pasajera,/que nos conduce por las formas y tragedias del otoño"; " prolongaciones que se mueven con resonancias y vibraciones suficientes, para multiplicar y difundir", "marcados por un frente horizontal, de líneas y ritmos negativos".

Si analizamos el vocabulario que se emplea para nombrar lo subjetivo éste resulta igualmente abstracto: conciencia, vida, camino, naturaleza, huella, tiempo, paisaje, belleza, mar... estos son algunos de los sustantivos, no demasiado abundantes, que sostienen el conjunto. Dos son pues las opciones lingüísticas, los polos de vocabulario alrededor de los que el poemario organiza prioritariamente su léxico: o marcas espaciales y magnitudes físicas, o un vocabulario de tipo simbólico que reserva pocas sorpresas al lector de poemas, pues está formado por palabras marcadamente asociadas con una "lengua poética" convencional, de signo existencial, metafísico, religioso casi. Me refiero al conjunto de términos que rápidamente identificamos como pertenecientes a lo poético en su modulación hegemónica hoy en España, la materialidad de la legua poética consensual, pendiente aún del glosario que sepa objetivarla ${ }^{7}$. Este vocabulario del yo lo componen aquí palabras que pertenecen a la

\footnotetext{
${ }^{7}$ No puedo presentar una descripción de esta lengua poética consensual, que funciona como referente prestigioso en el espacio poético hoy en día, en competencia claro con otras variantes y modulaciones. Haría falta un trabajo de corpus para poder presentar evidencias de su existencia y de sus características, tarea, además de tediosa, llamada a resultar inútil. Intentando una descripción orientativa, que al menos sirva para establecer el sentido que le voy a dar a este término y a otros términos vecinos a lo largo de este trabajo, diré que se caracteriza por a) presentar un alto grado de abstracción, en particular en lo que se refiere a sustantivos del ámbito de las emociones o de los procesos mentales, los que, frecuentemente, llegan a reificarse, al modo de ideas que existiesen de modo trascedente y exento, b) su teoría estética es siempre idealista y, de algún modo, platónica (la belleza existe -y a veces preexiste-, la tarea del poeta es buscarla, formalizarla, comunicarla; la belleza ilumina, mejora, cura, salva (pero nunca se nos dice a qué, de quién, de qué violencias concretas, de qué poderes reales); la belleza (que carece de forma, es una idea) está en cuerpos o en paisajes; c) práctica ausencia de determinaciones materiales, sociológicas, políticas... salvo cuando se convocan como temas literarios, para ser inflexionados irónicamente en el discurso poético pero, y esto es la clave, sin comprometer en ningún modo la naturaleza, condición y viabilidad de la enunciación lírica; d) el esquema comunicativo poeta-poema-lector se salvaguarda en todos los casos: aún sus propias variantes (del tipo "no entienden mi poema", "no soy capaz de escribir mi poema",
} 
koiné poética española, tan asociadas con esa lengua poética codificada que circulan como monedas gastadas del intercambio lírico: se reconoce en ellas su marca de haber llevado sentidos poéticos, pero aquí resuenan como si estuviesen huecas.

Entre ambas series de sustantivos abstractos (marcas espaciales o vocabulario del yo) no hay casi correspondencias. A veces los adjetivos destellan y producen otras sinapsis distintas que historizan o particularizan el tono del poemario. En otras ocasiones son sustantivos de una serie corporal los que realizan ese cruce, los que permiten instalar una presencia concreta entre las marcas espaciales del dominio y el mundo cartesiano de expresión inmaterial que define el ámbito del yo lírico que habita en él: dedos, piel, caricia, manos, mejilla, labios, son los términos que atribuyen algo de cuerpo a ese yo sustraído de la física y le fuerzan a interaccionar corporalmente con el espacio.

Es ésta, aproximadamente, la superficie de un mundo. De esto es, en rigor, de lo que el libro habla. Podríamos asumir la tesis de que se trata de un libro de poesía metafísica, que asistimos, desde regiones frías, al relato confesional de un yo que unas veces realiza su particular Extravío en la luz, y cuenta cómo Arden las pérdidas, o que, en otras ocasiones, presenta sus propios Fragmentos de un libro futuro, o los celebra como cuando No amanece el cantor, por situar este libro en el espacio lingüístico, filosófico y metafísico que Antonio Gamoneda o José Ángel Valente han construido alrededor de la luz y de la visión, a los que Juan Pastor directamente apela en sus paratextos, invitando a leer este libro como otra singladura poética semejante, nueva épica de la fenomenología poética. De este modo, la participación del lenguaje simbólico de este libro en la koiné poética actual, se realiza también como acto de crítica literaria, tomando por referentes autorizados de la misma algunos autores (habría que añadir a los también citados Claudio Rodríguez, y a Gonzalo Rojas, nacionalizado a través del Premio Cervantes 2003), y algunos libros como puntos cardinales de la escritura del libro que nos ocupa aquí.

En resumen: entre la fenomenología y la metafísica, se trata de un poemario realizado con honestidad, con un pie en el mundo de la materia y otro en un hipotético mundo de almas, con un vuelo místico capaz de abrir una reflexión sobre eventuales preocupaciones universalizadas (el paso del tiempo, la melancolía del curso unidireccional de la vida, la posibilidad y el límite de la memoria, la ensoñación

\footnotetext{
"para qué escribir con la que está cayendo fuera"), el canal comunicativo no resulta afectado en ningún sentido; e) radical apostolado del negro sobre blanco, página limpia con palabras, por lo que, aunque se escriba en internet, es como si el sermo poético no hubiese asumido determinaciones formales después de la segunda revolución industrial; f) clasicismo, ecleticismo y posmodernismo (y a veces simbolismo) como coartadas perfectas, teóricas y morales; g) defensa a ultranza de la autonomía del espacio poético y de la libertad total del creador para reproducir estas prácticas de escritura sin pudor, sin crítica, sin vergüenza y sin pausa; h) falta de distancia crítica y de autoconciencia de las categorías teóricas con las que se opera, lo que suele generar múltiples contradicciones argumentales, también dentro de los poemas; i) secularización de esquemas morales católicos como léxico último de la enunciación poética. Afortunadamente, no todo es eso, pero sí creo que esa es la tonalidad dominante, sin ninguna duda. La propia falta de una articulación poética fuerte permite que múltiples estilos (convertidos ya en tendencias), que se suponen a veces enfrentados, contribuyen a sostener ese mismo consenso formal: desprovistos de una articulación completa (y extratextual), los estilos ya son sólo marcas textuales.
} 
del regreso...) y que cumple su trayecto lírico mediante una lengua adecuada a tales dominios abstractos, desmaterializados en dicotomías básicas (día-noche, blanconegro, color-gris, línea-extensión, tiempo-viento), reducidos a su denotación mínima, y su connotación máxima. En resumen, un poemario que, en forma y fondo, lidia con una escritura (y comunicación) de la muerte, con la desesperanza, y con cuanto hay de frágil y de precario en el ser humano.

Cabría además entrar en diálogo con la obra anterior de Juan Pastor, para certificar, con la fórmula convencional, que hay una vuelta sobre temas y preocupaciones entrevistos en las páginas de libros precedentes, que nuevas variaciones se ejecutarían sobre líneas de voz que se han mantenido continuas en el tiempo, al mismo tiempo que se depura su voz poética, y ésta gana en contención y en expresividad. La marca formal más evidente de un relato tan previsible sería el desarrollo del versículo como vehículo poético, que ha adquirido plasticidad y libertad respecto a libros previos, y que, aún cuando convive con otro tipo de versos, los atrae y absorbe en un ritmo cadencial y litúrgico ${ }^{8}$.

\section{LAS VENAS CON POCA SANGRE, LOS OJOS CON MUCHA NOCHE.}

Cabe decir, en todo caso, que éste es un libro difícil de leer por lo críptico. Que en él se produce una insistencia en construir poéticamente la mirada (el lugar de la mirada, su posibilidad, sus condiciones perceptivas...), pero también por disimular la ansiedad que esta afirmación provoca. Se señala y se vela la expresión de una pérdida de matiz en los paisajes que el poeta figura, como si ese movimiento en el sentido (disimular que el poeta no puede ver lo que dedica tanto esfuerzo a tratar de ver) fuese análogo a una pérdida de visión de otro signo. Ese movimiento en el sentido incorpora un cierto gesto barroco, no sólo por la declaración de orfebrería, por la exhibición técnica -domino de matiz- contenida en el propio título del libro, sino por la posibilidad de reestablecer un sentido entre esas tinieblas, recuperar otra visión oculta tras estas sombras retóricas, que acaba por romper con la lógica propia de la poesía metafísica,

\footnotetext{
${ }^{8}$ Esta idea, implícita pero repetida en mi argumento, alude a cierta distensión lingüística muy marcada en el estado actual de la poesía española contemporánea, vinculada a la canonización de ciertos tipos de voces y registros que subrayan un tipo de enunciación vinculada con una antropología esencialista condensada alrededor de valores católicos secularizados. Esta cuestión, la del carácter lingüísticamente católico de una parte importante de la poesía española escrita y estudiada en los últimos años, y, aún más allá, de la crítica destinada a interpretarla, pide a gritos un análisis riguroso. Cabe, en realidad, la sospecha de estar ante un espejismo crítico: son más los modos académicos de hablar hoy de poesía en España que otras posibles formas de leer nuestro archivo reciente. Aquí me basta con apelar a un cierto tipo de tono dominante, que de alguna forma condensa las voces consagradas de la poesía española actual. La denominación de poetas jóvenes (estos pueden tener casi cuarenta años...) ha sido una herramienta útil para desarrollar ese dispositivo de hermenéutica católico-secular, identificado normalmente como clasicista, restringiendo al ámbito juvenil toda voz que no se articula paradigmáticamente en esos términos y que, aún así, requiere de un procesamiento crítico. Si a este esquema añadimos la ironía (todo lo posmoderna que se quiera) como coeficiente de corrección interpretativa, podemos describir a grandes rasgos un modo dominante de escribir, editar y leer poesía hoy en España (y tal vez no sólo allí). Por último diremos que el momento de la canonización de un autor responde a una reactivación de este dispositivo (cripto)religioso y sus figuras meditativas asociadas, como resulta evidente a la luz de las polémicas últimas sobre los distintos pésames que ha expresado Antonio Gamoneda.
} 
dominante en cierta franja del campo poético actual, introduciendo bajo su lenguaje un régimen de lectura alegórico: no es todo abstracto, hay un código, y hay una llave, que permite que este lenguaje se abra sobre su afuera, que apele a una referencialidad externa donde el poema se explique.

Proponiéndole a este poemario una estirpe barroca, cabría citar el famoso verso de Góngora, en la Fábula de Angélica y Medoro, "las venas con poca sangre, los ojos con mucha noche", que alude a las condiciones en las que Angélica, en un albergue "que la guerra dejó por escondido" encuentra a Medoro, moribundo, desangrado, con los ojos cerrados. Este verso ha sido frecuentemente interpretado como una secreta poética del momento culterano, como la inscripción bioliteraria ${ }^{9}$ del signo autorial de Góngora: el de ser un autor sin legitimidad en una sociedad basada en la posesión de sangre limpia ("las venas con poca sangre"), y, que al carecer de esa legitimidad heredada, reclama mérito a través del dominio individual de una escritura inaccesible ${ }^{10}$. Para compensar la carencia de sangre, cabe un exceso de oscuridad, un echar "mucha noche" a los ojos.

Hay mucha noche en los ojos que indagan este dominio del matiz. Y para entrar en este libro hay que, con Garcilaso, "perder los ojos que te vieron" y "dejarnos con otros que te vean". Es necesario revelar las condiciones materiales de estas pérdidas de luz, memorias del matiz, obsesión por la sombra, para ver, detrás de ellas, una fenomenología de la ceguera, en un poeta -Juan Pastor- que siempre ha entendido la poesía y la literatura (desde la escritura a la edición) como una forma de vida y como una forma de compromiso. Es el signo bioliterario del poeta, su propio cuerpo, el que se inscribe en este mundo de sombras, memorias de la luz, y pasos en falso:

El tembloroso latir de mis dedos. Pórtico. Pedestal
que se anuncia
sobre cataratas y pasos en falso (17)

Este es el pórtico del libro, que se anuncia como pedestal sobre ese reino de ambiguos ámbitos y de espacios que sólo se dominan con el tacto. Se trata de una poderosa metáfora de la escritura poética: la del poeta que ve con los dedos. Ver con los dedos convierte a la escritura en una operación de visión otra, de revelación de una realidad extrañada, simbólica, cifrada en un indescriptible braille. Las referencias a esa condición paradójica, la de dejar de ver para poder comenzar a ver, son abundantes, y siempre se expresan a través de la actividad de la escritura, construyendo el espacio del poema (página en blanco, extensión sin visión) como lugar diferencial respecto del mundo, lugar al que volver los ojos, quedando en ese mismo gesto restringido el mundo a la condición de territorio sin visiones. Vedado de visión. La importancia que tiene esta clave en el poemario se explicita en el interior del poema central del libro, dando razón del título de éste: "Sólo tengo frente a mi una poderosa masa de color sin horizontes y dominios de matiz" (47). Esta fórmula adquiere variaciones numerosas, por ejemplo "prevalece el color que nos deja en la retina su matiz", o, más importante,

\footnotetext{
${ }_{9}^{9}$ Para el uso que hago de la noción de bioliteratura, remito a otros trabajos $(2007,2008)$.

${ }^{10}$ A propósito de la referencia a Góngora, cito, en prensa, el libro de Víctor Pueyo, Góngora: hacia una poética histórica, que supone un aumento de temperatura en las lecturas políticas del lenguaje barroco y sus estrategias de legitimación en el interior de la cultura letrada de la época.
} 
"somos la fidelidad de una imagen que se repite con sus variaciones y matices de color" (43).

Esta línea de significado no es nueva en la obra poética de Juan Pastor. Podríamos decir con propiedad que es el tema central de su obra de madurez, construida como variaciones sobre tal cuestión, que aún han de adquirir connotaciones éticas y políticas en estos mismos poemas, como veremos. Tan determinante resulta la temática de la ceguera que, desde ella, es posible recorrer los títulos de sus obras para poder verlos de esta manera nueva: Claridad de la nada (1987), Espacios de luz hacia la línea (1993), Cuando se nos deja ver (2004). Y esta temática se hace explícita en un poema de Dominios de matiz, donde se releen, desde el presente, los versos de la obra de juventud, otorgándoles un sentido nuevo en esta economía de la mirada, en la que la intertextualidad dobla los signos de los versos. Los versos en cursiva pertenecen a Claridad de la nada (1987):

Estoy en medio y sentado entre dos mundos. Entre mis propios sentimientos y mi sueño.

Aquellas catedrales de luz en el horizonte por las que tanto he vivido.

$[\ldots]$

Sombras de historia que recuerdo, mezcladas todavía con el odio de nuestra acotada

y seccionada vida. [...] (69-70)

La historia muta en sombras, el tiempo de la escritura se plantea como paréntesis desgajado entre presente y pasado, línea divisoria que es el propio verso, y que separa luces y sombras, del ayer y del hoy, sobre la fábrica del cuerpo y sus retinas. Pero, al tiempo, la introducción de una marca formal (las cursivas, que se acompañan de notas al pie que revelan la procedencia de esos versos), quiere llamar la atención sobre el sentido histórico (su desarrollo histórico en vida y obra) que tiene la temática de la ceguera para este poeta.

\section{Y NOS HARÁN MÁS CIEGOS}

Sí. Éste es un paréntesis abierto. Donde no hay principios de referencia ni matices de color.

Y nos resulta imposible porque nos cuesta demasiado aguantar un espacio tan limpio y definido.

Pero tendríamos que insistir. Porque no es posible tanta indiferencia frente al color. (49)

De nuevo con Rimbaud: ¿matices o color?, ¡matices de color! En este caso las cursivas son mías, porque lo que quiero es preguntarme aquí (¿preguntarnos?) por ese nosotros que se ha introducido repentinamente en los poemas, ese nosotros que ha sido deslizado con habilidad, casi sin darnos cuenta. ¿Quién es ese plural que amenaza con quebrar la lógica lingüística de una poesía metafísica, que vuelve problemática, que hace entrar en crisis la ficción comunicativa base de este tipo de poética, es decir, la de existe un yo que habla solo en medio de la nada? ¿quién es/somos esa persona cuarta que explicita el tejido que, en la tarea de la lectura, se/nos une con aquel yo ensimismado en sus dominios? $\mathrm{O}$, dicho de otro modo, ¿a quién implica esta mirada?, ¿qué otro círculo de sentido tiene que configurar esta escritura para poder-nos apelar comunitariamente?, ¿es posible moralizar esa "indiferencia frente al color", hacer-nos partícipes de la misma, reclamar-nos un compromiso respecto de ella? 
La mirada se trabaja en este poemario como un tejido que implica a los demás, hasta conseguir volverlo un tejido que nos implica. Esos otros toman eventualmente la forma de cómplices en las dedicatorias, se les insinúa (poco) entre versos, o se les incluye a través de las citas. Esta poética de la mirada crea otro espacio donde, dice Pastor desde Valente: “El problema no es lo que sé, sino el ver / mismo. La mirada, no el ojo" (59), es decir, obliga a cuestionar la posición de la mirada como un lugar ético ${ }^{11}$. Quién mira a quién y desde dónde, quién puede mirar o puede no mirar, quién produce las imágenes y a quién son ofrecidas, son algunas de las preguntas que interrelacionan esta ética, y que se abren en el espacio de la lectura. $\mathrm{O}$, citando desde otro ángulo el título del libro de Pastor anterior a este, ¿qué es lo que ocurre Cuando se nos deja ver? ¿En qué sentido la experiencia extrema, bioliteraria, de esta vista hurtada, de esta sombra en los ojos, sirve para ver otras cosas, para echar otra luz sobre ojos otros?

Declara Pastor en el texto que introduce la tercera (y determinante) sección del poemario: "Estoy en mi sitio y sobre el poder de tu conciencia. Aunque caminar para romper la esperanza establecida es algo que nos cuesta y termina con la frontera de un paisaje que divide" (57). Semejante declaración busca explicitar la relación de miradas que une cuerpos con pronombres a través de la lectura, quiere organizar ese intercambio basado en una relación de poder que distribuye cuerpos, miradas y espacios. Establecer los parámetros de esa relación de poder, que el sermo poético tiende a sublimar en la clave superior de la transmisión de belleza o de saber, constituye aquí la condición de posibilidad para una alianza entre ese tú y ese yo en desigual relación de mirada, que debe conducir a un nosotros ("que nos cuesta") capaz de "romper" la "esperanza establecida", expresión que nos conduce al último espacio de significación que es necesario considerar en este libro.

Porque... ¿qué es eso de una "esperanza establecida”? De pronto, una nueva serie lingüística se descubre detrás de algunos textos del poemario. Aparecen en ellos otros signos, los de un vocabulario, hasta ahora latente, que cobra especial intensidad en la tercera sección de estos Dominios. Hablo de ciertas expresiones marcadamente políticas: "regreso a la multitud", "la dura realidad", "el sistema"12. En este sentido, si esta voz afirma que existe una "esperanza establecida", sólo cabe preguntarse quién establece esa esperanza y en qué consiste ésta. En los términos de una poética de la mirada, significa reflexionar sobre la relación entre poder, imagen y realidad: quién

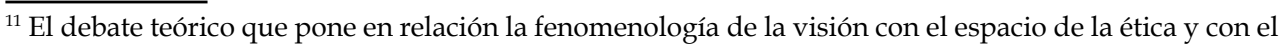
de la política no tiene término. Aún en las coordenadas específicas de nuestro contexto tendría múltiples posibilidades de articulación. En este caso, Santiago Alba es el autor que me sirve para imaginar una entrada lectora en el mundo de Pastor, a propósito de su texto obligado Capitalismo y nihilismo. Dialéctica del hambre y la mirada, donde desarrolla la idea de un "nihilismo espontáneo de la percepción" como lugar desde el que pensar críticamente el capitalismo a propósito de su fase última.

${ }^{12}$ Junto con los demás términos que aquí se le asocian, la cuestión del "regreso a la multitud", y de los regresos de la multitud, ha ocupado al pensamiento político transformador de las últimas décadas, gracias al impresionante cuerpo de saberes y reflexiones desarrollado por los politólogos italianos y los movimientos autónomos. A propósito de la expresión aquí señalada, remitimos al libro clásico de Paolo Virno. A propósito de los estudios culturales de ámbito hispanófono, cabe mencionar la reciente penetración del vocabulario de estos estudiosos en el análisis de objetos culturales.
} 
genera qué imágenes para hacer ver qué cosas y para enmascarar cuáles. Desde ahí cabe preguntarse por qué, en otros poemas, se habla de convertirse o ser convertido en imagen. En definitiva, esta tercera sección invita a preguntarse qué es lo que nos obliga a ver las imágenes que vemos, pero ahora las imágenes no son sólo el fruto fenomenológico de unos sentidos incapacitados para percibirlas conforme su naturaleza, sino una realidad segunda, producida por instancias externas al sujeto y a su comunidad de pronombres, y que amenazan la posibilidad de que ambos puedan identificarse autónomamente, pronominalizarse, fuera del ámbito de influencia de estas imágenes impuestas.

Pero conscientes, de que nos dejamos envolver por la sutileza y el engaño.

Queremos permanecer ahí para vivir alejados, pero muy cerca, de la modernidad establecida por el sistema.

Aunque luego sucede que después de un día tras otro. De otro y detrás de otro, siempre terminamos comprando esclavitud. (43)

"El sistema" ha descrito "la esperanza" y establecido un determinado tipo de "modernidad", que articulan un ámbito político hipócrita que promueve y defiende una determinada mirada inspiradora sobre qué significa el hombre en sociedad pero que, en realidad, se organiza a través de la distribución de desigualdad y de violencia. En este punto no cabe ambigüedad sobre el sentido de esta escritura. La fenomenología de la ceguera ha dejado de ser una marca autorial de tipo biográfico: al escribirla, al alegorizarla, por las propias condiciones de su comunicación (cuerpos y pronombres), ésta alcanza un nivel donde se resemantiza políticamente.

La ceguera se ha politizado. Así, la ceguera es también nuestra ceguera. Y, por lo tanto, la oscuridad es colectiva, es la de la "modernidad" (truncada, barroca, espectacular, posmoderna) que "el sistema" establece, mediante un mercado de esperanzas, imagos, ilusiones, en compra-venta, que enmascaran, ocultan, impiden ver relaciones de poder, esclavitudes. "Modernidad" resulta el término clave de la serie, que apuntala el sentido histórico-político de nuestra actualidad que, en el contexto del fin de siglo español bajo cuyo domino este libro fue escrito, apela a la autoafirmación compulsiva, histérica, de haber superado todos aquellos déficits que hacían del país un espacio anómalo respecto del huso europeo (Delgado), y la reconversión de este complejo periférico en la exaltación acrítica y celebrativa del neoliberalismo tecnológico y los flujos de capital del llamado milagro económico (López Hernández y Rodríguez López), momento discursivo que cuajó en un lema tan reciente que resulta aún más hiriente su ruina: España, la octava economía mundial.

En la España del colapso del ladrillo, de la precariedad y de la fuga de capital y de cerebros, de la celebración nihilista del milagro de la multiplicación de las plusvalías y de los billetes de quinientos euros, hay que dejar de ver para comenzar a ver, reconocer en los lemas, espejismos mediáticos y reinado de la publicidad, el mundo de la apariencia y de la falsedad detrás del que se descifra, a través de otro tipo de mirada, poética, una verdad en todo término política: "la belleza que genera cuando amanece la utopía y su color". Desde esta perspectiva, cabe releer versos a los que antes habíamos atribuido una notable gravedad metafísica, en la órbita de 
una ética y una política poética sostenida sólo por una firme imaginación de lo social. Porque poesía comprometida quieren ser versos a priori fenomenológicos como los ya analizados: "no es posible tanta indiferencia frente al color. Frente a una riqueza tan característica y llena de futuro" (49).

"Esperanza establecida", "sistema”, "poder", "esclavitud", "utopía" no son términos políticos cualesquiera. Forman un vocabulario preciso, de un lenguaje que se relaciona generacionalmente con la experiencia histórica colectiva de la transición española, y, particularmente, con la experiencia histórica colectiva de construir y socializar una nueva lengua democrática ${ }^{13}$. Lo diremos claramente: son elementos de una lengua marxista, que una vez determinó el modo de afrontar la lucha por la democracia en España, garantizó las identidades colectivas capaces de llevarla a cabo, y supuso un modo de ver e interpretar la realidad, e, solidariamente, una determinada forma de entender la poesía ${ }^{14}$. Esta lengua, desaparecida del discurso público, y aún del campo literario, es procesada en este poemario como compromiso ético del poeta con una identidad colectiva a la que guardar fidelidad, y al cabo, como garantía de una continuidad identitaria en la propia biografía ${ }^{15}$. Se conserva, pues, como un precioso tesoro, debajo de estos versos.

El sustrato profundo del verdadero dominador del matiz, su verdadera identidad, es la del activista cultural y la del poeta comprometido. El poeta que convoca esta lengua quiere marcar socialmente, al menos para los iniciados, para aquellos que sabemos de

\footnotetext{
${ }^{13}$ El relato historiográfico sobre la transición en los últimos años ha tenido que asumir la existencia de una serie de sujetos colectivos cultural y políticamente organizados que, a través de su movilización intensa durante diversos periodos de los años setenta, determinaron el campo de posibilidades máximas en el que esa transición podía verificarse, abriendo su "espacio de posibles", tal y como, entre otros, ha probado Ferrán Gallego, El mito de la transición. La crisis del franquismo y los orígenes de la democracia. Esa experiencia cívica, que he estudiado en diversos trabajos, es la que determina la creación de identidades colectivas en ese tiempo y todo un conjunto de memorias posibles y de problemas en el reconocimiento de las mismas. Sobre este particular véase Lo llamaban transición (Labrador 2010).

${ }^{14}$ El citado libro de Ferrán Gallego se hace eco de la importancia identitaria que esa lengua colectiva puede llegar a tener, y los problemas que sus fracturas incorporan hoy en el debate de afectos alrededor de la historiografía transicional. En términos poéticos es necesario referir la importancia decisiva que determinado régimen de representación poética (y una forma de leer desde él la tradición nacional en clave cívica) tuvo para una o incluso dos generaciones, durante la transición y en sus vidas posteriores, que demuestran, otra vez, que detrás de los procesos de concurrencia de formas poéticas en el espacio público están en juego ecuaciones más amplias entre identidades colectivas y modos de representación.

${ }^{15}$ El concepto de "continuidad identitaria" lo tomo de Alessandro Pizzorno (1989). En su teoría de la identidad, Pizzorno desarrolla la noción de "círculo de reconocimiento" como estructura psicolingüística y social que mantiene estables las identidades a lo largo del tiempo, y permite el reconocimiento del sujeto. Cuando los "círculos de reconocimiento" se fracturan, la identidad del sujeto se descompone. Una aplicación no prevista de la teoría de Pizzorno concibe la posibilidad de la lecto-escritura en sus formas románticas (bioliterarias) como un modo sui generis de círculo de reconocimiento. Entre ese cripto-mantenimiento de la identidad generacional al paso del tiempo, y el desreconocimiento de la misma en el presente (figura frente al espejo), fractura que debe ser recompuesta mediante la escritura, circula esta poética de la mirada, explorando las quiebras en la representación colectiva de la ciudadanía en la España contemporánea. En todo caso, como a propósito del debate propuesto sobre la economía política, la mención a Pizzorno quiere ser fundamentalmente una invitación a renovar los modelos teóricos sobre la identidad con los que se realiza la crítica de poesía en las coordenadas españolas, normalmente definidos por un esencialismo naif o por la pervivencia de esquemas católicos y de sus prejuicios antropológicos, y su moral del pecado.
} 
donde proviene ese vocabulario, su condición fiel a esa identidad juvenil, primera, a su compromiso con la fundación de un postfranquismo de signo democrático, al margen del tiempo que haya transcurrido y de la erosión que ha sufrido esa lengua en las décadas mediantes ${ }^{16}$. Recordemos que sólo es en virtud de esa erosión, de ese deterioro del lenguaje democrático, que cabe explicar por qué estos términos aparecen encriptados, cifrados en el paisaje lingüístico desreferencial de este poemario.

Poesía cripto-comunista. En un tiempo histórico, el nuestro, que se escribe otoñal, en esta "estación otoño" en la que pareceríamos históricamente detenidos, cuando se estaría cumpliendo la profecía de Rafael Sánchez Ferlosio de que habrían de venir "más años malos" que nos harían "más ciegos", esa actividad barroca, culterana, de echar noche sobre los versos para ver mejor, es subsidiaria de la experiencia política identitaria que el lenguaje marxista garantizó. Así, se realiza en la última sección de este libro, un réquiem por el nosotros que fuimos que, en realidad, expresa la aspiración de volver a ser otro nosotros.

Hoy no queda nada sobre mi piel. Pero sí que deseo recuperar la huella, para poder vivir en paz.

Muy lejos. En la distancia y al otro lado de los hilos manejados por el poder.

Donde todo es. Donde todo parece realidad y donde todo se decide.

\section{2.}

Pero es otoño y el mar se detiene. Aunque sí cantan sobre sus olas, con sus cadencias de vuelta y de regreso hacia la multitud. (63)

Cuando el mundo que dio lugar y sostén a ese lenguaje y a esas identidades ha desaparecido sin que se notase, y en su lugar hoy sólo queda la ausencia de un lenguaje colectivo capaz de explicar la compleja y fluida relación que se da en nuestras sociedades entre plusvalía, sociedad y trabajo, la tarea del poeta quiere ser "recuperar la huella" de aquella experiencia histórica, como un afuera del poder. Ese dominio (ámbito poético que es aquí ámbito de comunicación -y conspiración- entre cómplices lectores, después de ser ámbito de lectoescritura privada del poeta) se representa aquí como espacio de autonomía respecto del estado y respecto de las esferas económicas. Mediante tal representación quiere conectarse con otros tiempos de fundación de lenguaje, sí, pero, al tiempo, ese lenguaje quiere trasladar hacia un futuro su potencial posibilidad política, su "regreso hacia la multitud". Esa doble forma de diferir la esperanza, de conectar el pasado y el futuro, permite, mientras tanto, mantener la guardia frente a la

\footnotetext{
${ }^{16}$ Este concepto, el de la devaluación del lenguaje es una pieza clave en mi lectura de Dominios de matiz, pero también en mi interpretación de las problemáticas relaciones de la poesía española contemporánea con sus pasados demoenergéticos. Se trata de otro concepto que requiere una articulación teórica más rigurosa, y una red de explicaciones sociohistóricas que no caben en este artículo, pero podemos, aquí y ahora, entenderlo como una experiencia histórica, la de los miembros de aquellas comunidades morales y lingüísticas en transición que descubren, veinte años después, que ya no saben hablar de lo que les/nos pasa juntos. Rafael Chirbes lo resume del siguiente modo: "Cada generación vuelve a recrear, digamos, sus ideales. Pero como han vaciado prácticamente todas las palabras de sentido, y la gente se agrupaba por palabras.... Ahora vemos ingenuos esos tiempos de Franco en los que las palabras libertad o amnistía podían hacer daño. Ahora no hay palabras que les hagan daño, porque ha desaparecido la clase obrera. No tiene sentido porque se ha difuminado, ya no hay. Ha desaparecido el concepto de revolución. No sé qué conceptos hay. Cuando no hay conceptos, no hay manera de agruparse. Habrá que elaborar un nuevo discurso" (Chirbes 2003).
} 
presunta naturaleza ficcional de un presente "donde todo parece realidad", espacio de actualidad que conforma el lugar de la ganancia y de la decisión, el modo en el que “el sistema ha establecido la modernidad".

Frente a la promesa moderna que esta generación asumió en su juventud transicional, de desarrollo social y humanista, aquí lo que destaca es el carácter fantástico de esa otra modernidad del consumo y el espectáculo, en el tiempo de su gran crisis sistémica. En medio de la ceguera que construye el poemario, ceguera metáfora de nuestro presente histórico, cabe encontrar cadencias de vuelta hacia un nosotros colectivo, una multitud depositaria de una virtud política capaz de iluminar ese reinado de tinieblas exteriores. "Siento que estoy pesadamente lúcido, entre estos dos surcos y tantas invocaciones comunes" (69). Una vez más, en gesto marcadamente inscrito en nuestra tradición literaria, es el sujeto desplazado el que puede ver, aquel que, por tener sombras, tiene luces, el que "siendo ciego, alumbra y adiestra en la carrera de vivir".

El trabajo del poeta comprometido, del editor independiente, es un trabajo contracultural, una vía propia y escondida, una lenta, larga y laboriosa tarea, civil y democrática ${ }^{17}$. Ello se marca de manera completamente explícita en el final del poemario, en los últimos versos del último poema:

\section{Presiento un camino en soledad. Largo y abrupto. Muy pesado y marcado por la indiferencia. \\ Aunque seguimos y también podemos decir que florecen los espacios (78)}

Promesa de mantener una ética de la mirada que es ética de la escritura y arte para la vida. En este, con Eduardo Haro Ibars, “otoño llamado democracia donde los hombres duermen" (220), la tarea de reconstruir el tejido civil, de hacer "florecer espacios", trabajando desde la idea de la autonomía, es el lugar que el yo lírico se autoimpone para la acción política, donde la imaginación de la amistad representa una táctica política. De alguna manera, la poesía última de Juan Pastor encripta y resuelve el acertijo, que Antonio Machado, otro gran poeta de los ojos y otro gran teórico de la mirada, y compañero de viaje de esta generación, había formulado con lucidez amarga, hace un siglo, en la sección xii de sus Proverbios y cantares (1912).

\footnotetext{
¡Ojos que a la luz se abrieron

un día para, después,

ciegos tornar a la tierra,

hartos de mirar sin ver!
}

Se trata por todos medios, al menos a propósito de uno mismo, de evitar que se cumpla (y que de ello quede constancia por escrito), aquella irónica paradoja, la

\footnotetext{
${ }^{17}$ Cualquiera que haya seguido la trayectoria de la editorial Devenir en sus veinticinco años entenderá que en esta práctica se juntan vida y obra. Devenir ha mantenido una práctica editorial singular en el espacio de la edición de poesía en España. En ese sentido, podemos hablar de un modelo que se quiere autogestión. Caso singular: Juan Pastor es un poeta que se autoedita, que produce las estructuras culturales necesarias a su voluntad de expresión pública, en lo que es un modelo de organización cultural heredado de la transición y que hoy cuenta con abundante desarrollo en el contexto español, y está siendo objeto de importantes debates globales, en las relaciones entre ciudadanía, autonomía y libertad de expresión en democracia.
} 
de mirar sin ver teniendo ojos, paradoja donde fracasa el proyecto emancipador que configuró en su ética y en su lenguaje las ramas principales de la poesía española del pasado siglo, como ahora veremos.

\section{LOS OJOS DE LOS HIJOS DE LA IRA}

Hemos abierto las formas de este libro sobre otras voces históricas, sobre otros territorios de lenguaje, para entender cómo las lenguas consensuales que modelan nuestro presente (también poético) están en realidad atravesadas de tensiones que, como en una guerra de raíces, nos remiten a tiempos y a espacios que no caben en un libro y obligan a tomar en cuenta, a hacerse cargo de lo que está más allá de los límites de esa misma lengua, de lo que no cabe en su consenso. Quepa volver sobre un aspecto que ahora requiere un mayor desarrollo ya que nos servirá para conectar la escritura y significados de Dominios de matiz con un problema estético y ideológico de mayor alcance dentro dela tradición poética española, que afecta a sus modos deinstitucionalizarse y ser interpretada. Mencioné, en dos tiempos, que era necesario alumbrar cierto vocabulario de Dominios de matiz desde la tradición de poesía comprometida del tardofranquismo: primero, al establecer cómo las keywords del poemario remitían a unas determinadas textualidades de la lengua poética nacional y a unas cuantas de sus voces autorizadas; segundo, al explicar la naturaleza del diálogo que este libro mantiene con la poesía social o poesía comprometida, entendida ahora como una cosmogonía poética articulada alrededor de la lucha (simbólica, poética, discursiva) contra el franquismo. Ahora es el momento de indagar algo más en esta conexión: la que establece una continuidad, la vigencia, de una determinada lectura de la tradición poética de la segunda mitad del siglo XX, desde la idea de que la imaginación social que garantizaba aquellas escrituras inconformes (en su más amplio sentido, desde sus múltiples modos de textualizar la disidencia) debe ser un valor añadido en la práctica poética del que no cabe desprenderse hoy, valor que, en último término, se basa en una muy determinada definición de lo poético como ámbito continuo respecto de lo social. En las siguientes páginas trataré de reflexionar sobre tales condiciones, planteando en qué medida la pregunta por el lugar de la mirada, y la tematización de la visión como construcción poética y política, puede suponer una entrada diferente en el archivo poético español contemporáneo, y proporcionar una diferente óptica para una crítica de la poesía actual.

Para iniciar tal aproximación es necesario hacerse cargo de lo que significaron las tradiciones poéticas comprometidas en nuestro contexto, entendiéndolas, en primer lugar, como privilegiado modo de imaginación comunitaria en el ámbito estudiantil antifranquista, donde aquella poesía funcionó como lengua común, identitaria (compartida más allá del grado de compromiso en la militancia política concreta), hasta el punto de constituir el paisaje estético y moral de la juventud sesentaiochista, del mundo progre, desde aquellos que militaban en el PCE hasta aquellos que simplemente leían Hijos de la Ira, desde los que fueron después altos cargos y hasta los que fueron buenos profesores de instituto. En todo caso, la circulación del lenguaje poético bajo Franco dispone, desde el inicio, de una capacidad análoga a la hora de 
sostener el diseño de mundos morales alternativos, de imaginar espacios identitarios que respondiesen a reglas éticas y a una ordenación de lo real diferentes a las que dictadura garantizaba. Desde muy pronto, el vocabulario de aquellos poetas, con todas sus variadas modulaciones sociales y rehumanizadas, se descabalga del vocabulario público hegemónico y, fundamentalmente, del sentido común que lo sostiene, desde los toros de Rafael Morales o desde los muertos de José Luis Hidalgo.

De este modo, muy poco a poco, pero desde muy temprano, se irá estableciendo una relación fluida entre la escritura de una poesía que aspiraba a hacer circular imágenes de lo social y la reconstrucción (y reconquista) de ámbitos para lo público, de espacios de autonomía comunicativa respecto del estado, respecto de las múltiples instituciones (y sentidos comunes) que lo constituían en tiempos franquistas. La relación de la poesía comprometida, combativa, disidente, y de sus parientes líricos y musicales, con la reconstrucción de lo público (y de los públicos) es un territorio vital para explicar los cambios de sentido y rupturas que, desde los años sesenta, se producen con el lenguaje franquista en la esfera privada (primero) y pública (desde 1965) ${ }^{18}$. También a raíz de esas rupturas (y obviamente no sólo a partir de ellas), empiezan a circular otras representaciones distintas de lo social y de las relaciones entre sujeto, lenguaje y comunidad, representaciones alternativas que, además, no estaban necesariamente formalizadas a través del dispositivo lengua-nación.

La intensidad y relevancia de estos procesos es la que dotará a la figura del poeta de un aura prestigiosa y carismática, como artifex de una lengua civil, de una lengua moral para las instituciones democráticas, que lo convertía en representante político de la comunidad avant la democracia. En esa capacidad de representación, que por restringida que fuese sociológica y cuantitativamente en los últimos años del franquismo se extendía más allá de las aulas universitarias, cabe encontrar las razones de la inmensa acumulación de capital simbólico que la poesía adquirió en la época, y de las razones de su institucionalización en el interior del aparato cultural de los primeros gobiernos post-transicionales, capital cultural del cual viven todavía aquellos que consiguen gestionarlo, por más que se hayan cortocircuitado o resemantizado los vínculos (estéticos e ideológicos) de las instituciones (públicas, privadas y concertadas) con ese archivo de lenguajes de análisis social, transformación moral y combate político de los años cincuenta, sesenta (y aún setenta), y con su tradición de los treinta y de sus exilios y pervivencias y de sus ediciones clandestinas.

\footnotetext{
${ }^{18}$ Estos argumentos sobre la socialización de la poesía como lenguaje moral en el contexto del antifranquismo no son particularmente originales, aunque tal vez incorporen una cierta secuencia sintáctica no tan a menudo preservada en las narrativas frecuentemente inmanentistas que se han ocupado de tratar de tratar de explicar la poesía de la posguerra. Mi argumento sería vecino al de Jordi Gracia en La resistencia silenciosa, al asumir que la escritura literaria actúa como espacio en el que garantizar algún tipo de autonomía lingüística e ideológica bajo la penetración de las lenguas franquistas del poder, siempre que añadiésemos dos elementos clave: de un lado, la anormal, violenta, problemática relación que se establece entre esfera pública, esfera privada y prácticas de escritura, y, de otro, el poder consensual de penetración que tiene el franquismo en el campo cultural, en su producción de sentidos comunes, que se heredan más allá de la transición, que afectan a la misma imaginación del dispositivo "historia literaria nacional" y que tienen en el concepto de "normalización" su tótem simbólico mayor.
} 
Por más que, en los últimos treinta años, y de modo destacado a finales de los años noventa, se hayan producido múltiples intervenciones por parte de críticos, poetas, estudiosos (y con obvias, notables y brillantes excepciones), sobre el siempre difuso espacio (histórico) de la poesía social-comprometida-conversacional, generando una abundante bibliografía en la que se me permitirá que no me pierda, la capacidad histórica que tuvo el espacio poético de representar un espacio moral fuera del franquismo va mucho más allá de la evidencia de que los poemas, en si mismos, no transforman la realidad. Haría falta un estudio capaz de leer la producción de poesía social como imaginación de comunidades, que entienda la circulación de esos libros también como la circulación de imágenes de sus autores (y con ellos, de una determinada lectura de la tradición poética, y una determinada antropología moral, en el sentido de Taylor, como una indagación, en definitiva, en la historia literaria como historia nacional alternativa) y que explique cómo esa circulación sirvió a la construcción real de comunidades discursivas en el contexto de movilización ciudadana tardofranquista y transicional ${ }^{19}$.

Esta bibliografía última ha expresado sus sospechas sobre el carácter literario de aquella poesía en dos sentidos a menudo contradictorios, que, en realidad, responden a una misma determinación teórica. En primer término, se ha tratado de cortocircuitar críticamente la circulación social de la líbido poética, apelando a toda una serie de espejismos críticos (notablemente la calidad literaria, magnitud totémica de poderes mágico-religiosos) que convierten el espacio poético en un espacio autorreferencial, inmanente e idealizado; tensión que se resume en la siguiente tautología: "poesía comprometida, poesía no comprometida, lo importante es que sea buena poesía", afirmación no menos vacía, no menos tramposa que la también recurrente "un poema es, ante todo, una obra de arte" ${ }^{20}$. En segundo lugar, se ha tratado de restringir la ya

\footnotetext{
${ }^{19}$ Esta también necesitada de estudio específico. Pero basta con revisar las bibliografías académicas de la época para ver los conflictos (también generacionales) que se establecen, en el ámbito de la historia o de la filología, entre lecturas históricas. Los años setenta son en el ámbito de la filología un territorio (hasta cierto punto) experimental en el que se indagan lecturas y recuperaciones de voces, formas de entender la relación entre textos y tiempos históricos y entre literatura y sociedad, o al menos, de emergencia de una bibliografía nueva que nos habla de los años de la transición como años, de nuevo, de imaginación de la historia literaria como historia nacional alternativa. Citemos, a modo de simple, pero notable, ejemplo, dos trabajos de José María Balcells: sus antologías Poesía castellana de cárcel y sus Poemas del destierro, siglos XVI-XX, dos libros que revisan la historia literaria desde dos nociones tan fuertes como las de exilio y prisión, categorías centrales de la historia cultural española bajo el franquismo, que, de este modo, se convierten en instrumentos imaginativos para redescribir la historia (literaria) nacional, en una secuencia diferente a la que obligaban la narratología providencialista hegemónica bajo Franco, más en conexión con las operaciones de hispanistas del exilio como Américo Castro, y sus herederos en Norteamérica como Paul Ilie.
}

${ }^{20}$ Estamos ante la naturalización de una determinada definición idealista de la estética (idealista), como si no hubiese multitud de teorías de lo estético, y su sacralización, convertida en principio moral básico (nomos) del campo literario. Afirmar en sus espacios que la calidad literaria no existe, que es sólo un acto performativo, es poco menos que una herejía. Resulta muy llamativo que esta crítica ha afectado por igual a la poesía social, conversacional, comprometida (con todas sus variantes), como a los proyectos de las vanguardias, desacreditados por excéntricos, por idealistas, por elitistas (qué ironías). No negaremos la existencia de un conflicto entre vanguardia y socialrealismo pero, en determinado momento, comparten parecidas antropologías y una misma teoría de la comunicación poética, aunque teorías de la forma radicalmente opuestas y una mayor complejidad en el análisis comunicativo. Esa antropología 
problemática noción de compromiso al orden del lenguaje, como si se tratase de algo que está dentro del poema, y que, por lo tanto, cristaliza en él (y en él se objetiva, estudia, analiza o rechaza). Más escasas son las aproximaciones que han tratado de entender que la condición comprometida de un poema o un poeta no la decide el poeta, ni su crítico, sino el carácter social de la lengua que ese poema garantiza y el tipo de valencia que puede adquirir en sus múltiples modos de ser recibida, circulada, interpretada, replicada. Aquí es necesario invertir la carga de la crítica: en los tiempos de fundación poética, y los años sesenta y setenta lo fueron, lo más interesante que ocurre con lo poético no ocurre dentro de los poemas.

El problema es que sobre el debate, onanista, sobre los vicios y las virtudes de la poesía comprometida o no comprometida, con sus múltiples y previsibles variantes, se ha gestionado otro debate, más interesante, pero frecuentemente inexplícito, que es el que tiene que ver con la autonomía del campo literario (Bourdieu) ${ }^{21}$. Como ya traté de esbozar en otra parte (2006), la histeria con la que se defiende la autonomía del ámbito poético de cualquier otra condición interpretativa (o proximidad imaginativa) que quepa imprimírsele (como el carácter socialmente continuo del lenguaje frente a la discontinuidad de sus momentos litúrgicos) sólo es proporcional a la hoy absoluta irrelevancia social de dicho ámbito, por más que se declaren o no comprometidos sus insiders. Igualmente, el entusiasmo con el que, por ejemplo, jóvenes poetas performan esta condición institucional sólo es proporcional a su deseo de verse protegidos y promovidos precisamente por la autonomía institucional de dicho ámbito. Entonces, no resultaría extraño pensar que la declaración unánime del principio de discontinuidad social de la comunicación poética no sería más que, de nuevo con Bourdieu, "el reconocimiento de las posiciones codiciadas" (38) ${ }^{22}$.

En este contexto, la relevancia del libro analizado en este artículo no se pretende mayor que la de ser un caso de estudio desde el que poder establecer una secuencia capaz de conectar las relaciones entre ética, estética y política, alrededor de la noción de mirada, en el diálogo de la poesía española actual con una tradición edificada en esta confluencia. Dominios de matiz formaliza esta tensión entre tiempos históricos y proyectos poéticos, y aquí resulta pertinente por su capacidad de apelar a aquel momento inicial de la democracia en el que dicha confluencia garantizaba una lengua poética con capacidad de construir un ámbito de lectura del mundo más allá de la esfera autónoma de los propios productores de poesía. La ceguera a la que el poeta apela treinta años más tarde también tiene entonces una relación con esta tradición: implica la conciencia

(heroica) del poeta, y la teoría de la visión poética, y de la comunicación, que se deriva ha sido razón de su compartida condena en el infiernillo donde han puesto a arder a las Musas del 68.

${ }^{21}$ Hago notar que estoy empleando dos diferentes nociones de autonomía. La primera, vinculada a la imaginación política, que está tomada de los politólogos italianos, y de la tradición teórica que viene de Castoriadis. La segunda, de la sociología de la cultura, central en la obra de Bourdieu, es la que voy a utilizar a propósito de mi análisis del campo.

${ }^{22}$ Cuando se saluda a un conjunto de plumas vestidas con ropa de diseño como "una generación que ha tomado el relevo de la palabra" debería explicarse qué quiere decir eso de tomar "el relevo de la palabra", como si "la palabra" fuese algo más que el nombre de la secta, como si "la palabra" se pudiese "tomar" (Ruiz Montilla 11). 
de que la lengua poética clasicista-simbolista, con la que se puede caracterizar el lenguaje poético hegemónico hoy en España, y en la que este libro también se reconoce, ha ocultado otros modos de descripción de lo real; implica el reconocimiento de que esta lengua poética no sirve para ver lo real, cuando, además, este momento de lo real, por su condición espectacular, ha complicado sus condiciones de acceso, la posibilidad de su visión. Como si nos hubiésemos quedado sin palabras para ver y para hacer ver.

La apelación de Dominios de matiz a ese pasado histórico y literario (que vimos cómo se introducía en cursiva dentro de los propios poemas) es también la marca escritural de una reflexión sobre la formación literaria del autor como poeta y como ciudadano. En el contexto de los años setenta, en la educación literaria de Juan Pastor, como exponente de un tipo muy concreto de joven poeta en transición (Labrador 2008), confluyen lenguajes que, treinta años después pueden no entenderse vecinos. En el acceso a la poesía, en la búsqueda de elementos, de piezas, mecanismos, que permitiesen ver más allá del poema, porque eso es lo que se jugaba en la educación literaria entre, al menos, 1965 y 1975 (Vázquez Montalbán 65-85), lentes oculares las suministraban tan pronto poetas como Gabriel Celaya o Blas de Otero, Miguel Hernández o Antonio Machado, Cernuda o Lorca, Álvarez Ortega, José Luis Hidalgo o José Hierro, Antonio Gamoneda o León Felipe.

En ese contexto de lecturas lo que tiene lugar es la activación de tradiciones poéticas y la lectura de los nuevos libros de poemas en el interior de un dispositivo hermenéutico que conectaba intensamente poesía y mundo (Labrador 2008: 220-250). No se leía desde el árbol genealógico de la historia literaria, sino desde la necesidad que dos (incluso tres) generaciones en transición tuvieron de elaborar una nueva descripción de la realidad que, desde luego, también incluía una descripción del franquismo como cosmogonía y, por tanto, un relato (histórico, pero, sobre todo, político y moral) de la historia española y de sus sentidos, tarea esta donde los poetas demostraron ser de gran utilidad ${ }^{23}$. Incluso en poetas de la órbita novísima, sorprendería reconocer las profundas huellas social-realistas que dejó su educación literaria en los años sesenta, no tan incompatibles con su estética de ruptura posterior (aunque ésta los separase de la formación nacional que ofrecía el social-realismo), en la medida en que, al cabo, los poetas disidentes de posguerra compartían una matriz político-moral continua, de tipo romántico, con los textos de la tradición moderna europea, desde Rimbaud a Rilke, desde Pound a Ginsberg (Labrador 2008: 180-300).

Así, a modo de ejemplo, un libro como Descripción de la mentira (1977) de Antonio Gamoneda pudo ser leído como máquina de visión político-profética. En un artículo, Julio Llamazares recordaba la lectura que hizo de ese texto cuando apareció: en su memoria consta cómo entonces se leía en grupo, se interpretaba colectivamente (“yo y mis amigos"), se usaba la literatura (y la poesía) para ver política y moralmente la

\footnotetext{
${ }_{23}$ Para entender el prestigio del que gozaba esta lengua poética, y su carácter identitario en la cultura sociológica antifranquista, basta con pensar en el reconocimiento a la cultura política de la oposición que supuso la cita de Antonio Machado con la que Adolfo Suárez terminó su discurso en defensa de la Ley de Asociaciones políticas "hombres de España, ni el pasado ha muerto, no está el mañana -ni el ayer- escrito".
} 
realidad (identificando "la mentira del título de su libro con la que este país había vivido durante años"), de verla de modo distinto a través de la experiencia extrañante del lenguaje cotidiano (y del sentido común que un lenguaje de época garantiza) que proporciona la estética ("se trataba de una poesía distinta, hermética, pero bellísima, $\mathrm{y}$, sobre todo, llena de interpretaciones"), experiencia con consecuencias de todo tipo para el sujeto que la vivencia (“No hace falta que yo diga que para mí aquel libro sería fundamental").

Aprender a mirar. Aprender a mirar desde otro sitio. Esa parece tarea propia de las lenguas poéticas y de la literatura como tecnología sociocultural (Chirbes 2002: 13-35). Los libros en esta perspectiva son máquinas de visión. Lugares desde los que mirar. Posiciones de mirada. ¿Pero qué es exactamente una máquina de visión en esta perspectiva? ¿Cómo reconstruir una historia de la poética desde categorías fenomenológicas tan débiles, que nos sirvan para entender las historias literarias también como historias culturales, alrededor de esta cuestión de la organización de la mirada en el espacio poético, sin caer en una nueva reificación del lenguaje literario? ¿Cómo hablar de una práctica poética como construcción social de la mirada y hablar al mismo tiempo de lo que esas máquinas de visión permiten ver?

\section{4. ¿SERÁN LAS GAFAS?}

Lo que sigue será sólo un apunte con el que proponer un desplazamiento del caso de estudio que me ha ocupado en este artículo hacia un problema más general, con el examinar los límites y las condiciones de lo que podemos llegar a ver desde lo poético en el contexto contemporáneo. La construcción social de la mirada, entendida desde lo expuesto, puede defenderse como un vector clave en la historia de la poesía española del siglo XX. Sin embargo, los nervios que unen al ojo y al poema, son varios $\mathrm{y}$ responden a fenomenologías contrapuestas y, en ocasiones, incompatibles.

De este modo, en los esquemas perceptivos que se repiten en el contexto de la poesía actual, encontramos una preeminencia del lenguaje de la vista, fuertemente asociado a actos de escritura poética. Sin embargo, este lenguaje se encuentra intervenido por otro campo léxico que lo contamina y redefine: el vocabulario de la luz aplicado a la poesía, desde un esquema que entiende la poesía como revelación. En principio, la metáfora de lo poético como luz que ilumina la realidad y permite verla, es decir, como foco de luz, pero también como ojo suplente, como prótesis ocular, se podría retraer hasta Platón, y, entre tantos de los modernos, a Rimbaud. Hacer semejante operación ofrece escaso sentido histórico, más allá de certificar la universalidad de una metáfora. Sin embargo, entender con Benjamin, que detrás de la escritura (y representación pictórica) de la luz y de los actos de mirada que la rodean a finales del siglo XIX se está reorganizando lo social y transformando la estructura de las ciudades a través de la aparición de electricidad y del alumbrado, y entender cómo esta luminosidad hace aparecer un mundo nocturno nuevo, la bohemia, vital para la historia de las formas de vida en Occidente (Heller), que producirá una auténtica revolución en la sexualidad y la estética (Felix de Azúa) significa, con Stoichita y Cordech, darle relieves a una historia 
de la sombra que sea también una historia de lo que se nos deja ver. Una historia de la mirada es una historia sociocultural de la mirada; una historia de la mirada poética debería serlo también.

En este sentido, afirmaría que la luz que ha inundado la poesía española contemporánea y el vocabulario lumínico de sus $\operatorname{críticos}^{24}$, tiene poco que ver con las formas tecnológicas y societales de la luz entre nosotros, con su producción, circulación y compraventa como energía, por imaginar un mero itinerario de lectura. Tampoco es la luz cancerígena que atraviesa la capa de ozono vulnerada. Tiene poco que ver con las velocidades de la luz: sigue siendo una luz platónica. La luz que permite a muchos de los poetas españoles mirar es una luz revelada, una luz sacra, que proviene de un más allá y que desde luego no parece ser una radiación electromagnética reducible a amperios o vatios. El espacio (omnímodo) de la luz y de la mirada es en estas escrituras un espacio religioso, donde el poeta está en posición de espera de una gracia (luz) que, lenguaje mediante, le permita ver, o no, (ver como sinónimo de entender) lo que normalmente no se puede ver: verdades reveladas.

En esta capacidad de ver (o no ver) lo que los demás no ven (o tampoco ven), un cierto tipo de poeta de hoy cree obtener su razón de ser poeta $(\mathrm{y}$, fundamentalmente, de ser como tal reconocido, en el sentido de Pizzorno). Posiblemente ese dominio de la videncia defina la identidad social del poeta en la modernidad ("Je dis qu'il faut être voyant, se faire voyant", "Digo que hay que ser vidente, hacerse vidente”, con Rimbaud), la de ser un especialista de la mirada, un analista de las condiciones de lo real a través de una serie de disciplinas (en unos casos técnicas, metodologías, o, incluso, espirituales, mágico-religiosas) que le permiten la creación, y comunicación, de imágenes (visiones) que remiten al mundo.

Sin embargo, la máquina de visión que los poetas españoles contemporáneos traen de serie posee un mecanismo muy simple: el poeta está a oscuras, de pronto la luz llega, y él ve (o no llega a ver, o ve con dificultades) algo, alguna cosa, esquema en el que no resulta difícil reconocer la secularización de la epistemología platónico-

\footnotetext{
${ }^{24}$ De verdad que no exagero, todo seleccionado por el azar googleano: Diego Jesús Jiménez Iluminación de los sentidos (Hiperión 2001); Carlos Alcorta, Ritual de la luz (2008); Ángel L. Prieto de Paula "Desolación luminosa" (El País, Babelia, 07 agosto 2010); "Pasajero de la luz. La sombra y la apariencia" (Juan Goytisolo, El País, Babelia, 08 enero 2011); "Huesos de Sol" (Javier Rodríguez Marcos, El País, Babelia, 08 enero 2011); “Juan Salido-Vico y su obra: “Tramar la luz", ganadora de La Voz + Joven 2009” (Web Caja Madrid); "Que las contradicciones personales pueden alumbrar otro modo de vida. [...] Su claridad secreta llega directamente al corazón del lector" (Juan Antonio González Iglesias, El País, Babelia, 25 diciembre 2010); “de ese tipo de luz límite habla la condición de la poesía [...], esa luz es el acontecimiento por el que imagen y mito personal se producen simultáneamente desde su origen" (Miguel Casado. La poesía como pensamiento. Madrid, Huerga y Fierro, 2003: 131-132); “Una buena ocasión para descubrir (o redescubrir) a un poeta que se reencuentra día a día con el mar y da fe con serenidad de sus deslumbramientos, [...] una minuciosa sensualidad que es a la vez fecunda visión de lo real y celebración de su misterio inagotable" (Ángel Rupérez, El País, Babelia 27 de diciembre 2003); “Pureza es, tal vez, por uno de sus costados, precisión expresiva, desnudez que no nos impida ver el bosque de las palabras [...]. Pureza es, también, iluminación, luz súbita, revelación" (En Joaquín Benito de Lucas La experiencia de la memoria (Poesía 1957-2009). Madrid: Calambur Poesía, 105, 2010); “ANTES DE LAS PALABRAS, qué suavidad su luz, volviendo a inaugurar cada barrote, anochecida apenas" (Ana Gorría, Punto de Partida, Nueva poesía española, número 161). Se pueden alargar las menciones ad nauseam.
} 
tomista donde, siempre, a) la visión viene de fuera (y, en muchos casos, procede de una verdad externa y trascendente, aunque sea literariamente), b) el poeta se encuentra en posición inicial de oscuridad e ignorancia, c) en el poema hay un desplazamiento de b) a a), a través del que el poema resuelve (hasta un cierto grado) esa tensión entre ser y no saber, $\mathrm{y}$, finalmente, d) el poeta, a través del poema, ofrece graciosamente a sus lectores la posibilidad de realizar subsidiariamente dicho tránsito en la lectura, de iluminarse por refracción, como si los lectores fuesen planetas.

Desgraciadamente, y siempre en general, los poetas españoles actuales ni siquiera se muestran muy conscientes de operar en el interior de este esquema, en las antípodas de las máquinas de visión que sostienen videncia visionaria de un Rimbaud, la videncia apocalíptica de un Blake, la prognosis de un Lorca o la alucinación como máquina de visión de un Hierro, porque en todos ellos no se trataba de lo que ellos podían ver, sino de lo que podían hacer que se llegase a ver. Así, operaban atravesados por las lenguas sociales de su momento, en conexión directa con espacios de transformación sociohistórica, y con esquemas fenomenológicos muy sofisticados, que dialogaban con la historia literaria como historia de los modos de mirada, como historia de las máquinas de visión.

Pero, sobre todo, la gran diferencia respecto de la mirada poética contemporánea es que, en estos poetas (y en otros innúmeros) es posible reconstruir históricamente las visiones que ofrecían: podemos llegar a decir lo que permitían ver. Yo no sé qué es lo que hoy nos permiten ver los poetas que ahora pululan, más allá de listas de sustantivos abstractos, sin materia ni forma: "el mundo es para nosotros un lugar extraño, porque existen imposibilidad y dolor, y entonces el deseo, la perfección, el anhelo de belleza, quedan, casi permanentemente, ajenos" (Luis Antonio de Villena cit. en Juan Antonio González Iglesias 18-19). Obvia decir que esa concepción del mundo, platónica y católica, se basa en la idea de una caída primera, que aquellos que vivimos en un mundo secularizado no solemos compartir.

Veámoslo en detalle con un ejemplo, escogido por el azar de google entre la múltiple producción contemporánea. Se trata de "Luz de invierno en el Gianicolo", un texto de un joven poeta que se encuentra, según sus propias palabras, "más en la estela de Auden que en la de Fofito" (en Ruiz Mantilla 16). Me refiero al asturiano Martín López-Vega, poeta en castellano y bable, neoculturalista y de fuerte influencia neopost-neo-novísima. El poema es muy representativo de modos de escribir actuales y de los problemas que incorporan ciertas visiones poéticas y, sobre todo, de los problemas que dejan de incorporar:

\footnotetext{
Estropeó todas las fotografías, aquella luz de invierno sobre los árboles del Gianicolo: demasiado intensa como para quedar bien fijada. Lo mismo ocurre con los momentos en exceso felices: la memoria no consigue después interpretarlos adecuadamente, otorgarles la luminosidad precisa. Quedan en la fotografía cosas que no están en ella: los racimos de muchachas americanas camino del bar Gianicolo,
} 


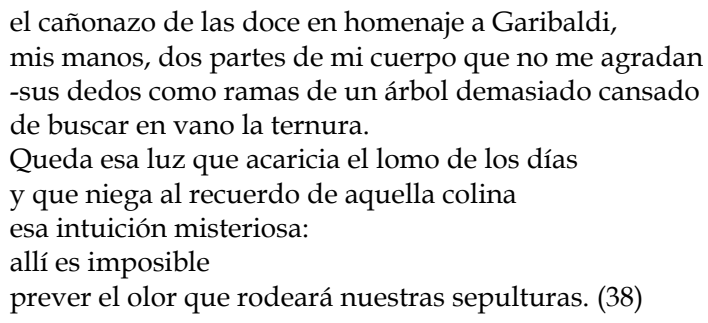

En algún momento habrá que reflexionar sobre qué puede significar el culturalismo en la era democrática de wikipedia. El efecto extrañante que el Gianicolo pueda tener para el lector se disuelve al conocer que es una hermosa colina romana del barrio del Trastevere. Con googlemaps streetview podemos ver la excelente panorámica de su mirador y el chiringuito con toldo amarillo y las copas de los árboles que estropean las fotos a este sujeto lírico, y si no le vemos a él es porque aquel día no estaba. En otro momento habrá que reflexionar sobre qué significa escribir sobre viajes (e, incluso, en este caso, plantearse una peregrinatio literaria) en la era de los vuelos baratos y el turismo de masas, en el contexto de la última década donde los españoles fuimos viajeros compulsivos. Cabe preguntarse cómo representar como experiencia poética trascendente una experiencia histórica que no puede desgajarse del turismo de contingentes humanos y del movimiento global de masas, y de su impacto sobre las ciudades muertas (Davis), lo que, en último término, se mete en el poema con esos racimos de muchachas americanas camino del chiringuito. Este sujeto lírico es un turista de masas, no hay duda, pero ¿cómo se hace cargo de ello? ¿Cómo mira desde ese mirador, como un turista que saca fotos sin parar inconsciente de su posición en un engranaje, como un viajero romántico que quiere ver a Roma en Roma como si él no formase parte de la masa de turistas, como si él tuviese el derecho a no formar parte, o como un sujeto que se hace cargo de los límites de visión de los lugares de mirada que tiene disponibles y aprende a ver a partir de esos límites?

El poeta nos plantea que es posible una experiencia viajera trascendente en esa colina como si nada hubiese cambiado desde el siglo XIX: salvo la cámara, claro. Pero ¿es ésta una cámara digital o una cámara convencional?, sería una pregunta relevante, cuando este poema no nos explica por qué no le salen bien las fotos a su protagonista. Es que hay demasiada luz, nos dice, y por eso las fotos se me estropean. No hace falta saber nada de fotografía, como es mi caso, para entender que este problema de luminosidad tiene que ver con la exposición, la abertura del diafragma y la distancia focal, para saber que una lente es como un ojo, y que salvo casos extremos como los de la luz de una explosión nuclear, la luz de un día de invierno un fotógrafo aficionado debería ser capaz de captarla con su cámara. La respuesta que nos da el sujeto lírico es sin embargo metafísica: los días tienen lomos, son como libros, que sólo pueden leerse (por fuera) cuando les llega (¿pero de dónde? ¿quién la ha encendido?) la luz. Y en esta colina existencial, que está debajo del turismo de masas, siendo todavía eterna, hay un impedimento metafísico que es, en realidad, una alegoría de la vida: hay demasiada luz, y no es posible hacer esas fotos, de la misma manera que, en las fotos, no se capta el olor de las sepulturas (y, además, ¿cómo olerá la mía?, se pregunta el poeta). 
Aquí estamos en una discusión diferente, porque reconocemos que existe una poderosa ecuación entre el debate sobre la representación, la expresión de la temporalidad y la imaginación de la muerte, como indagó Roland Barthes en La chambre claire: al paso del tiempo, la luz que ha atrapado químicamente la fotografía es la misma luz que ha tocado un cuerpo que ya estará muerto. Ése un modo en que se relacionaba la materialidad de la fotografía y de nuestra mirada, antes de la era digital (Amelunxen). Pero no es necesario avanzar tanto, porque en este poema la relación entre representación y muerte es simplemente una relación de incapacidad técnica: la memoria no puede registrar correctamente la vida, al igual que este señor no es capaz de sacar fotos. En este mirador no se ve nada, esas fotografías no enseñan nada y toda la verdad revelada insiste en esa incapacidad de ver, de entender, de comprender, lo que restringe el ámbito del conocimiento a una "intuición misteriosa", que, además, se nos ofrece como experiencia trascendente, metafísica y universal, que, implícitamente, se supone que nos tiene que hacer más sabios.

Todo lo que los poetas contemporáneos se muestran incapaces de ver y de hacer ver (con notables y poderosas excepciones), todo aquello que escogen no mirar, de lo que escogen no hacerse cargo, es la materia con la que trabajan poéticamente los $m c^{\prime} s$ españoles contemporáneos. El rap, esto es, la reproducción oral de un texto poético sobre una base rítmica se ha especializado en los diez últimos años en construir poderosas máquinas de visión poética. Veamos cómo opera, en nuestra discusión, una de ellas, en el tema "Gafas" del mc Elphomega en su disco El testimonio Libra. Veamos sólo su segunda estancia:

¿Serán las gafas?, ¿serán las gafas?, / miopía, hipermetropía, astigmatismo,/ mis gafas son dos lentes de cine. $(x 2)$

Guarda el respeto a este camello del crack óptico, si digo "palmarás balanceándote" es cómico, si digo "palmeras balanceándose" es hipnótico, es normal que vea de más con cuatro ojos, es lo más lógico. Vas con un fan de Harvey Oswald, notas que con los versos del gafotas flotas, te enseño el mar, mira, [tres tiempos de base sin texto] eso era el mar, ahora vuelve al 2 con 5 y te lo vuelvo a enseñar de gratis, en cada flow yo veo una mantis, mis dioptrías bailan el funk de Bootsy Collins y voltean el local, te entierro en cal con el pulso de los Coen al filmar, te puedo pinchar, lo telefónico es real porque lo veo por un cristal orgánico, siente pánico a mirar de más. Tras estas lonas, ¿no ves las demás personas?, yo tengo el zoom de un periodista en Cannes, veo cosas, el negativo de tu vista sana errónea, mi córnea es un banco de sal, el plano solar de un sat tras una Ray-Ban, destapo el plan como el dúo Redford-Hoffman, ¿no puedes verlo?, ya hice eso, adelantao como el tarot, creedlo, podéis moverlo. El track es del diamante, el verso es de Elphomega, intenso, esnifo cal, te veo muy tenso, te veo muy mal y pienso, estos cristales nunca mienten, ¿verdad?, ¿y que lo vea yo tan distinto es normal?, ¿serán las gafas?

¿Serán las gafas?, ¿serán las gafas?, / miopía, hipermetropía, astigmatismo,/ mis gafas son dos lentes de cine.(x2)

Ver la realidad con lentes de cine no es necesariamente montarse una película, sino emplear la educación cinematográfica para ver la realidad de un modo más complejo, con el bagaje simbólico, narratológico, fabulesco, que el cine proporciona. Las letras de Elphomega se caracterizan por su barroquismo y sus referencias culturales: al cine, al cómic y a la música. Estas se mueven siempre entre la obra de autor, la serie $\mathrm{B}$, el producto de culto y la cultura underground, en un mundo de producciones donde 
la cultura de masas se inflexiona para producir obras de vibración exigente y poderosa penetración simbólica, que constituyen ámbitos de reificación de la autonomía del espectador en la medida en que ofrecen resistencias formales, que, venciéndolas, obligan a una necesaria educación en la sensibilidad. El acceso a estas referencias culturales no es evidente: en muchos casos representan y requieren de una iniciación. Así, Harvey Oswald fue una pieza (y chivo expiatorio) de la conspiración alrededor del asesinato de John F. Kennedy. Robert Redford y Dustin Hoffman son los actores protagonistas de All the President's Men (1976) de Alan J. Pakula, película sobre el escándalo de Watergate. Bootsy Collins es uno de los músicos más importantes del funk. Sin embargo, este culturalismo está dirigido a guiar al lector en el interior de una biblioteca lectora y audiovisual posible, que representa el mundo contemporáneo con una complejidad desbordante, y cuyas entradas, en realidad, son tan francas como teclear en google sus términos. Es un culturalismo humanista: quiere hacer partícipe a su oyente de esas mismas referencias ${ }^{25}$.

En esta letra (lyrics) un cambio radical se ha operado. En el esquema de pensamiento que aquí encontramos no hay ninguna relación entre la luz y la imagenconocimiento: el acceso a las perspectivas, a las visiones no ocurre como iluminación (en el sentido platónico que establecimos), no se marca en el interior de un vocabulario de la revelación, no hay referencias a la luz, y, además, la imagen y el conocimiento se han segmentado, sus relaciones ya no son unívocas. Aquí una cosa es lo que ves y otra cosa es lo que entiendes. Derivado de esto, la primera cuestión que nos interesa del texto es una productiva contradicción (porque supone un cambio de paradigma) derivada de las propias características del rap: toda esta teoría de la mirada se gestiona a través del oído. Se trata de una visión telefónica ("lo telefónico es real”), es decir, de la posibilidad de ver a distancia a través del sonido, esto es, de integrar las condiciones tecnológicas de producción y transmisión de la información de nuestra época en el lenguaje poético.

Aquí una cosa es lo que ves y otra cosa es lo que entiendes. Este texto nos habla de un mundo en el que las visiones y las imágenes se confunden, donde no es posible diferenciar lo que viene de fuera, lo que sale de dentro, y lo que sólo ocurre en mi mente. Aquí visiones e imágenes posibles son múltiples, especulares, imposibles de controlar y verificar. En este mundo lírico de apariencias no existe la verdad, sino la multiplicación de las perspectivas y la duda de su capacidad de remitir al mundo. El sujeto lírico simplemente se sumerge y disgrega en ese mundo (y en ese proceso aprende). Allí el

\footnotetext{
${ }^{25} \mathrm{Si}$ un poeta como, Luis Antonio de Villena, por ejemplo, piensa que "en España somos 45 millones de habitantes y el público cultural como máximo llega a las 100.000 personas", un $m c$ como Elphomga trabaja desde una utopía de la socialización cultural donde, ampliando la comunidad de participantes, se estaría ampliando también la inclusión política en la misma. Dejemos de lado la mirada que Villena tiene sobre cultura institucional que le da de comer como si fuese la única cultura posible (y existente): en último término, parece que mientras un poeta se queja de que su "público cultural" (que le ha venido dado naturalmente, como otras personas heredan casas o acciones en bolsa) es escaso, mientras que un $m c$ piensa que hacer un público (moral, políticamente) es no sólo parte de su responsabilidad, sino que en eso precisamente consiste su trabajo y por eso su público (y no las instituciones) le pagan. Ni que decir tiene que mientras bastantes son los poetas que viven de la poesía y de sus actividades parasitarias, muy pocos son los $m c^{\prime}$ 's que han conseguido otro tanto con su rap, ni falta que hace.
} 
poeta ve cosas y las ofrece. Hace ver el mar en una sucesión de sonidos eléctricos: es decir, "hipnotiza", induce a la visión ("mira, eso era el mar"), desvela los mecanismos de producción de la visión, enseña a desconfiar de la naturaleza de las visiones dadas, justamente por su naturaleza fabricada.

Este es un esquema que se ajusta a la naturaleza teleproducida de nuestro mundo (Dupont). El mundo de visión de Elphomega se puebla de conspiraciones, poderes ocultos, cortinas de humo, satélites y teleobjetivos. En él la visión se organiza mediante tecnología militar. Lo rigen poderes ocultos, que no pueden ser vistos, los que determinan lo que se puede ver y lo que no, porque ver o no ver tiene aquí consecuencias políticas. En ese mundo, ver de más puede ser peligroso ("siente pánico a mirar de más"), porque lo que esta máquina de visión poética ofrece cambia las vidas, amplia las descripciones del mundo, sitúa a los cuerpos en zonas de riesgo. Diríamos con Baudelaire, que si nada es verdad, todo está permitido. La poesía rap como máquina de visión opera como una droga ("crack óptico"), que amplía lo que puede ser visto, sí, pero lo hace asumiendo todas las consecuencias de la visión bajo influencia, entre ellas la condena a una desubicación definitiva con la realidad "tal y como es", es decir, la fractura experiencial con los sentidos comunes que garantizan la posibilidad de una visión compartida, de una illusio social (Bourdieu 34-35) como ficción colectivamente sostenida.

Elphomega juega con las paradojas que siempre han relacionado conocimiento y representación, también en la tradición poética: "estos cristales nunca mienten, ¿verdad?", aunque, aquí, cristales sean también dosis de MDMA, una droga anfetamínica y empática, que amplia el mundo de las percepciones y transforma los afectos entre cuerpos, y, por tanto, la imaginación política, en el sentido de Amador Fernández-Savater (2010). En esta bivalencia, Elphomega trabaja también en el interior de tradiciones de "literatura drogada" (Labrador 2003b): Rimbaud ya advertía que el poeta se hace vidente a través de un largo, inmenso y razonado desajuste de todos los sentidos que le lleva a agotar en si mismo todos los venenos (esta es la palabra química por excelencia) para tan sólo guardar su quintaesencia ("le poète se fait voyant par un long, immense et raisonné dérèglement de tous les sens. [...], il épuise en lui tous les poisons, pour n'en garder que les quintessences" 69). Todo se reduce a una tecnología de visión: una lente, unas gafas, una droga, una letra de rap, que cambia la mirada del mundo. El trabajo del poeta consiste en suministrar dosis (lyrics) de esa droga visionaria. Esta química trabaja cerebralmente en la precisión del ajuste de ritmos silábicos y electrónicos, en los efectos perceptivos que generan las rimas, y en los efectos de contratiempos, síncopas y encabalgamientos entre textos y bases: hoy el hiphop ha recuperado la maestría técnica (en trabajo en lo que los estilistas llamaron el "nivel fonológico") que por escrito les está vedada a los poetas hace décadas, por la condición oral en la que estos textos rap se transmiten. Los $m c^{\prime} s$ recuperan esa maestría técnica, esa calidad fonética del juego poético, adaptándola, eso sí, a los cambios prosódicos y tonales que, con García Calvo, se han producido en el español oral urbano en los últimos cuarenta años (1998). 
Una última cuestión sobre estas gafas y sobre la antropología de este poeta, que se autodenomina "el gafotas", "el cuatro ojos", asumiendo los términos que tradicionalmente marcan en su primera juventud a individuos disfuncionales, con una socialización problemática, no grupal. Educación biopolítica en la diferencia: devenir vidente es cuestión de haber sido miope y haber elaborado esa diferencia identitariamente. El "cuatro ojos" es, pasado el tiempo, el que más ve. La capacidad visionaria es un defecto de percepción respecto del grupo, que separa al sujeto de él, sí, pero que también le obliga a la construcción de una visión autónoma, que el vidente trata de devolver al grupo como modo de negociar su diferencia y su reconocimiento (qué distinta resulta esta gestión del estigma, en el sentido de Goffman, de aquella que caracteriza a los poetas últimos, que reifican su diferencia de modo clasista: como si naturalmente tuviesen el derecho a disfrutar de un estatus moral que les hiciese distintos sólo por el hecho de declararse poetas). Al cabo, para este sujeto poético (en el rap la distancia entre identidad social del poeta y sujeto lírico no existe), no existe una visión normal, todo son problemas de lentes, fabulación de una sociedad enferma de los ojos, un país de ciegos, poblado de miopes e hipermétropes, donde son las dioptrías las que, al tiempo, impiden y permiten ver.

\section{UNA HISTORIA CIVIL DE LA MIRADA (POÉTICA)}

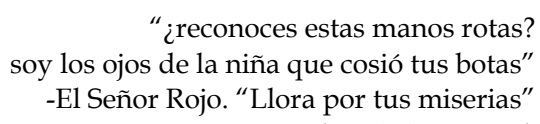

(Bagdad Rap 2005)

La distancia posible entre ambos paradigmas es, obviamente, inmensa, aunque no excluya la posibilidad otros paradigmas posibles, otras distancias, y otras formas de trabajar con ellos: siempre y cuando entendamos que nos conectan con cuestiones que no se juegan en la esfera poética, sino que obtienen consecuencias de mundo, aunque sólo sea como la responsabilidad que cabe reclamar de los productores simbólicos en la gestión del capital simbólico que les ha sido legado y que ellos administran y despilfarran, también económicamente, como si fuese este otro de los múltiples finales del estado del bienestar y sus instituciones.

Sería interesante imaginar una historia de la poesía peninsular contemporánea como historia de la mirada socialmente construida, aunque sólo fuese para desencajar ciertos lugares críticos que han podido restringir las formas de leer nuestros archivos poéticos. Este no será el lugar para ello, pero cabría simplemente marcar dos de sus momentos pasados. Uno, de naturaleza vanguardista, situado en los años treinta, que podríamos pensar desde la conocida Histoire de l'oeil de Bataille, desde la relación compleja que el surrealismo supo instituir entre órganos de percepción, órganos de reproducción y órganos de nutrición, y entre ellos y las heridas, lugar simbólico donde la vanguardia española supo conectar el imaginario nacional (vg. toros, santos, navajas) con las convulsiones políticas (y psicoanalíticas) modernas. 
La segunda de las máquinas de visión de esa historia posible consiste en un ojo ciego, en un ojo que ve estando ciego (José Luis Hidalgo: "solo quedan los ojos que preguntan en la noche total, y nunca mueren"; Dámaso Alonso: “Ojos abiertos, desmesurados en el espanto último, ojos en guiño, como una soturna broma, como una mueca ante un panorama grotesco"; Blas de Otero: "[sangre] sube hasta los ojos y no me deja ver, no veo más que sangre" ): en realidad, la obsesiva presencia de los ojos cegados y de las miradas ciegas en la poesía bajo el franquismo responde a la experiencia sociocultural de sentirse incapaz de asumir una mirada. Esta máquina de visión incorpora dos tiempos: primero, un tiempo en que el sujeto ha sido intervenido de modo agresivo por una instancia externa, perdiendo la vista (haciendo inviable una posición de mirada anterior, una mirada natural), y, un segundo tiempo, derivado de experiencia traumática de esa condena a la ceguera, en que el poeta comienza a ver cosas que los demás no pueden ver y, aún peor, en que el poeta está físicamente obligado a verlas. Su visión y la visión colectiva se hayan ahora en régimen de suplemento. En el fondo, es la ceguera de una época lo que ha hecho al poeta perder su vista, y es esa ceguera lo que le obliga a ver las cosas que sus contemporáneos (y muchos sus contemporáneos poetas) no pueden (o no quieren) ver, en virtud de ese trauma de haber perdido los ojos y de su elaboración a través de la escritura como prótesis de visión.

La contundencia de esa poética, la larga y profunda elaboración que ha tenido en nuestras coordinadas, obliga a reflexionar sobre lo llamativo que resulta que los poetas españoles contemporáneos (excluyendo a las voces de la longue durée, a los pocos cuerpos biopolíticos del siglo XX que aún puedan seguir hoy alucinando entre nosotros, y abriendo, también, espacio para integrar múltiples excepciones contemporáneas, y desde luego confiando en que el hiphop español será el Arca de Noe de la poesía española) tienden, como colectivo, a ver sin problemas. No necesitan ni usar gafas. En España hoy hay pocos poetas que oigan voces, y aún muchos menos poetas hay que vean muertos, por emplear la poderosa metáfora de The Sixth Sense (M. Night Shyamalan) ("I see dead people walking around like regular people", "veo muertos, caminando como gente normal"), que nos habla de una mirada que se hace cargo de la construcción histórica de la realidad, de cómo el presente se edifica sobre una historia de violencia, de cómo la sociedad de los muertos constituye también la sociedad de los vivos. Pocos poetas hay que expliquen qué es lo que ven o dejan de ver y de qué tradición de miradas (y de cegueras) se hacen cargo. Aunque afirmen que creen en "una idea fuerte de la tradición" (Ruiz Montilla: 16) no lo demuestran. Como si pudiesen ver solos, como si pudiesen ver por su cuenta, como si no estuviesen ciegos.

\footnotetext{
Vemos con ojos heredados. Quien no sabe que ha heredado sus ojos, ciego es. Entre el mirar y el ver hay muchos siglos de distancia, ya que el mirar es un fenómeno real y el ver es un patrimonio cultural. Nadie ve exactamente lo que mira. Miramos la realidad que tenemos ante los ojos, pero vemos, en cambio, lo que la evolución de las artes, lo que la historia de la cultura nos ha enseñado a ver. (cit. en Termes)
}

Quien esto firma es Luis Rosales, poeta antes sospechoso de miope que de visionario. Sustituyamos "evolución de las artes" por el relato de una historia de la sensibilidad y disputemos a fondo la definición de cultura que aquí parece abierta. Pero la declaración teórica que sostiene este pasaje pone en el centro la cuestión social 
y cultural, histórica, de los modos de ver, situando las condiciones estéticas en el centro de las relaciones dialécticas entre sujeto, mirada, mundo y escritura. La cita corresponde a un discurso, el que Rosales dio en 1985, en honra póstuma de Aleixandre. En ese mismo discurso, continúa defendiendo una teoría de la poesía que es una teoría de la mirada: "un poeta es, ante todo, un mirador del mundo; un poeta es una atalaya para ver la vida de una manera más bella, más patética, más concentrada y más serena". Hay muchas máquinas de visión posibles, pero, en todo caso, lo que Rosales hace es vincular decisivamente la cuestión de la poesía a la cuestión de una mirada construida históricamente, y, al tiempo, históricamente contingente. Este discurso no tiene lugar en un ateneo, sino en una montaña, ante un grupo de senderistas, poetas, familiares y lugareños, en el acto de inauguración de un Mirador, el Mirador de los Poetas, en la Sierra de Guadarrama, construido como homenaje a su memoria, por una asociación cultural vecinal de Cercedilla, lugar largamente vinculado al excursionismo de las élites (también culturales) madrileñas, que hoy forma parte de varias rutas de senderismo. Esta intervención de land art, de apropiación de un lugar paisajístico como lugar de mirada construido culturalmente (en el ámbito se dispusieron versos y libros, alrededor del punto panorámico, uniendo versos y prismáticos), es un intento, civil ("un hecho fundante" con Rosales), de problematizar y de comunicar esa condición sobreimpuesta de los lugares desde los que vemos desde la experiencia literaria. Un mirador es un lugar al que ir a mirar, como Rosales supone que debe ser la obra de un poeta. La tradición de miradas, de máquinas de visión, de voces que ven muertos, que supone una tradición poética, actúa también en ese sentido.

El debate teórico que pone en relación la fenomenología de la visión con el espacio de la ética y con el de la política no puede abrirse aquí, pero resultaría plenamente necesario entrar en él de cara a imaginar esa historia civil de la mirada poética, posibilidad con la que concluimos, historia posible que, al menos, nos haría conscientes de lo que han dejado de ver muchos de aquellos que hoy se hacen llamar nuestros poetas.

\section{BIBLIOGRAFÍA}

Alba Rico, S. (2007): Capitalismo y nihilismo. Dialéctica del hambre y la mirada, Madrid, Akal

Amelunxen, H. et al. (1996): Photography after photography: memory and representation in the digital age, Amsterdam, G+B Arts.

Azúa, F. (2010): “Degas y Picasso coinciden en el burdel", El País, 14 de noviembre.

Balcells, J.M. (1976): Poesía castellana de cárcel. Antología, Barcelona, Dirosa.

Balcells, J.M. (1977): Poemas del destierro. Antología. Siglos XVI-XX, Barcelona, Plaza y Janés.

Bataille, G. (1928): Histoire d'oeil, Paris, Flammarion, 1998. 
Barthes, R. (1979): La chambre claire. Note sur la photographie, Paris, Gallimard, Seuil, 2000.

Benjamin, W (s.f.): “T. Sistemas de Iluminación” en W. Benjamin (2005) El libro de los pasajes, Roff Tiedeman (ed), Madrid, Akal: 577-586.

Bourdieu, P. (1992): Las reglas del arte. Génesis y estructura del campo literario, Barcelona:,Anagrama, 2002.

Chirbes, R. (2002): El novelista perplejo, Barcelona, Anagrama.

Chirbes, R. (2003): “Entrevista a Rafael Chirbes. Fernán Chalmeta”, Molotov, 37, julio .

Davis, M. (2007): Ciudades muertas. Ecología, catástrofe y revuelta, Madrid, Traficantes de Sueños.

Delgado, E. (2003): “Settled in Normal. Narratives of a Prozaic (Spanish) Nation", Arizona Journal of Spanish Cultural Studies, 7, 117-132

Derrida, J. (1967): De la gramatología, Mexico, Siglo XXI, 1986.

Dupont, L. (2007): Téléréalité : quand la réalité est un mensonge, Montréal, Presses de l'Université de Montréal.

Elphomega (2007): El testimonio libra. Madrid, Zona Bruta, LP.

Fernández-Savater, A. (2010): “Apuntes (muy tentativos) sobre el pasaje al anonimato en primera persona" en L. Navarro ed. (2010): Industrias Mikuerpo, Madrid, Traficantes de Sueños: 340-352.

Gallego, F. (2008): El mito de la transición. La crisis del franquismo y los orígenes de la democracia, Barcelona, Crítica

García Calvo, A. (1998) “ Hablando lo que el ritmo habla. Entrevista con Javier Arias Navarro", Sarta. Revista iberorrománica de poesía y pensamiento poético, 3, 19-29

Gimferrer, P. (1995): Mascarada, Barcelona, Península

Goffman, E. (2003): Estigma. La identidad deteriorada, Buenos Aires, Amorrortu.

González Iglesias, J.A. (2004): en L.A. de Villena (2004) Alejandrías, 1970-2003, Sevilla, Renacimiento: 9-28.

Haro Ibars, E. (2001): «Scalextric» en E. Haro Ibars (1985) En rojo en (2001) Obra poética, Madrid, Huerga y Fierro: 220-2.

Heller, A (1989): “Existencialismo, alienación, postmodernismo: los movimientos culturales como vehículos de cambio en la configuración de la vida cotidiana" en A. Heller y F. Fehér (1989) Políticas de la posmodernidad. Ensayos de crítica cultural, Barcelona, Península: 232-47

Labrador Méndez, G. (2003a): “In stercore invenitur: Sacralidad, coprofilia y melancolía en Mascarada de Pere Gimferrer", Tropelías, 12-14, 219-233

Labrador Méndez, G. (2003b): “Poéticas bajo influencia: hacia un análisis literario de la literatura drogada", Pliegos de Yuste, 1 noviembre, www.fundacionyuste.org/ acciones/pliegos 
Labrador Méndez, G. (2006): “Sin novedad en el Parnaso. Teoría y práctica del discurso poético en el campo literario actual”, Hesperia. Anuario de Filología Hispánica, IX, 127-149.

Labrador Méndez, G. (2007): “Musa locura. Bioliteratura, política y psicoanálisis en la poesía de la Transición Española” en A. Druet y Sadi Lakhdari (2007): Actas de la Jornada de Estudios "El psicoanálisis en la cultura española", Paris, CRIMIC, www. crimic.paris-sorbonne.fr/actes/labrador.pdf

Labrador Méndez, G. (2008): “Poéticas e imaginarios de la transición española: campo, discursos, fracturas". Tesis doctoral. Universidad de Salamanca.

Labrador Méndez, G. (ed.) (2010): Lo llamaban transición, Salamanca, Mombasa.

Llamazares, J. (2007): “Descripción de la mentira”, El País, 25 de mayo.

López Hernández, I. y Rodríguez López, E. (2010): Fin de ciclo. Financiación, territorio y sociedad de propietarios en la onda larga del capitalismo hispano (1959-2010), Madrid, Traficantes de Sueños.

López-Vega, M. (2010): “Gianicolo y otros poemas", Clarín. Revista de nueva literatura, año $15,86,37-42$.

Pizzorno, A. (1989): «Algún otro tipo de alteridad: una crítica a las teorías de la elección racional» en Sistema, 88: 27-42.

Pueyo, V. (2011) Góngora: hacia una poética histórica, Barcelona, Ediciones de Intervención Cultural.

Rimbaud, A. (1871): “La lettre du voyant” en J.L. Cornille y S. Petronella (1997) L'Epitre Du Voyant: Alcide Bava/Arthur Rimbaud (Avril-Aout 1871): Etude, Amsterdam, Rodopi: 67-147.

Rimbaud, A. (1874): “L'Art Poétique" en Sophie Bogaert ed. (2000) Arthur Rimbaud. Poésies, Paris, Ed. Bréal: 104-108.

Ruiz Mantilla, J. (2010): “Poetas de aquí y ahora", El País Semanal, 13 mayo.

Stoichita, V. y Cordech, A.M (1999): Breve historia de la sombra, Madrid, Siruela.

Termes, R. (2003?): "Historia de los miradores de los poetas", Asociación Cultural Cercedilla http:/ / www.trotamontes.org/historiadelmirador.htm

Vázquez Montalbán, M. (1998): La literatura en la construcción de la ciudad democrática, Barcelona, Crítica.

Villena, L.A. (2008): “Estamos gobernados por ignorantes. Entrevista de Gema Genil”, Diario de Córdoba, 04 de abril.

Villán, J. (1978): El rostro en el espejo. Poema 1976-1977, Madrid, Colectivo “24 de enero". Virno, P. (2003): Gramática de la multitud, Madrid, Traficantes de Sueños. 